\title{
Terminal Pleistocene and Early Holocene Human Occupation in the Rainforests of East Kalimantan ${ }^{1}$
}

\author{
Karina Arifin
}

This paper presents results of archaeological excavations at two rock shelters and a cave in the Berau region of East Kalimantan. The investigations produced significant new evidence for the occupation of tropical rainforest environments along the Upper Birang River by human foragers from at least the end of the Last Glacial Period. The substantial bone assemblages, human burials and material culture recovered during excavation have provided important insights into modes of subsistence, burial traditions and technological innovations from the terminal Pleistocene through the Holocene. The observed patterns in human cultural and ideological behaviour correspond well with evidence from elsewhere in Borneo and across Island Southeast Asia.

\section{Introduction}

The island of Borneo has produced significant Palaeolithic archaeological deposits encompassing much of the Late Pleistocene and Holocene, from as early as 50,000 years ago. Most well documented archaeological investigations have focused on Sarawak and Sabah in the west, in Malaysian Borneo. Of these, probably the most significant excavations have concentrated on the Niah Caves, Sarawak, where Tom and Barbara Harrisson identified a deep, well-stratified sequence of archaeological deposits spanning the Late Pleistocene to sub-recent, and recovered anatomically modern human remains dated to ca. 35,000 BP (Harrisson, 1957, 1958, 1970; Brothwell 1960; Bellwood 1997: 172; Barker et al. 2007; Barker 2013). Subsequent excavations have illustrated the complexities of human frequentation of the caves, the diverse foraging strategies employed, changes in lithic artefact repertoires with the increasing utilisation of plant processing technologies and the emergence of burial traditions in the early to mid-Holocene (Zuraina Majeed-Lowee 1981; Rabett et al. 2013). Other notable archaeological investigations that have enhanced our knowledge of Bornean and Southeast Asian prehistory have been conducted at Lubang Angin and Gua Sireh (Datan 1993), Madai and Baturong caves (Bellwood 1988), Bukit Tengkorak (Bellwood 1989; Chia 1997) and Tingkayu (Bellwood 1997: 177-180). Some research has been undertaken in Kalimantan, for example, Chazine (1994, 2005), Chazine and Ferrié (2008) and Widianto et al. (1997) have all reported on excavations at various caves and rock shelters that have produced evidence of flexed burials typical of the early to mid-Holocene.

1 An earlier version of this paper was presented at the 17th Congress of the Indo Pacific Prehistory Association, Taipei, 2002. 
However, the potential of these large limestone karst landscapes to provide new and significant data on human occupation and adaptation to humid tropical rainforest environments in the region is yet to be fully realised.

This paper addresses some of the outstanding questions regarding Palaeolithic human occupation of eastern Kalimantan. Archaeological excavations were conducted at two cave sites and a rock shelter: Liang Gobel, Lubang Payau and Kamanis in the Berau region along the Upper Birang River. The investigations demonstrate that Eastern Kalimantan possesses a rich Late Pleistocene and Holocene archaeological record comparable with that discovered to the west in Sarawak and Sabah, and provide significant new insights into human occupation of the region, technological innovation and cultural and ideological developments.

\section{The archaeological investigations}

Units of Analysis: Each trench in the various cave and rock shelter entrances was excavated using $5 \mathrm{~cm}$, or in the case of LPY/D5 $10 \mathrm{~cm}$, spits. For accuracy in analyses, assemblages from each excavation pit were 'grouped' into different analytical units, which represent hypothetical units of activity, or phases of occupation. The 'boundaries' of each analytical unit were delineated by observations of the stratigraphic sequence excavated, and by the characteristics of recovered archaeological assemblages such as content and density of material culture. Thus, an analytical unit generally consisted of several $5 \mathrm{~cm}$ spits and straddled more than one stratigraphic unit. By distinguishing analytical units in this way it became possible to clearly determine spatial and temporal changes in the archaeological record at both the intra- and inter-site levels (Table 6.1).

Table 6.1 A summary of number of units recorded for Kimanis trenches KMS/C4, KMS/C8, KMS/TP and Lubang Payau LPY/C3; the numbers within the columns represent the spits and their depths below modern ground level allocated to each of the analytical units recorded for each site.

\begin{tabular}{|c|c|c|c|c|}
\hline \multirow[t]{2}{*}{ Unit } & \multicolumn{4}{|l|}{ Spit/Depth (cm) } \\
\hline & KMS/TP & KMS/C4 & KMS/C8 & $\mathrm{LPY} / \mathrm{C} 3$ \\
\hline I & $1-10(0<x \leq 50 \mathrm{~cm})$ & $1-10(0<x \leq 50 \mathrm{~cm})$ & $1-10(0<x \leq 50 \mathrm{~cm})$ & $1-8(0<x \leq 40 \mathrm{~cm})$ \\
\hline$\|$ & $11-21(50<x \leq 105 \mathrm{~cm})$ & $11-23(50<x \leq 105 \mathrm{~cm})$ & $11-27(50<x \leq 135 \mathrm{~cm})$ & $9-18(40<x \leq 90 \mathrm{~cm})$ \\
\hline III & - & $24-34(105<x \leq 160 \mathrm{~cm})$ & - & $19-32(90<x \leq 160 \mathrm{~cm})$ \\
\hline IV & - & $35-42(160<x \leq 200 \mathrm{~cm})$ & - & - \\
\hline V & - & $43-61(200<x \leq 295 \mathrm{~cm})$ & - & - \\
\hline
\end{tabular}

Source: K. Arifin.

The following information is primarily drawn from Arifin (2004). Archaeological investigations were conducted at three cave and rock shelter sites in a limestone massif in the tropical rainforest in the upper reaches of the Birang River, about $60 \mathrm{~km}$ in a straight line from the east coast of Borneo (Figure 6.1). The three sites investigated were Liang Gobel, Lubang Payau and Kimanis. 


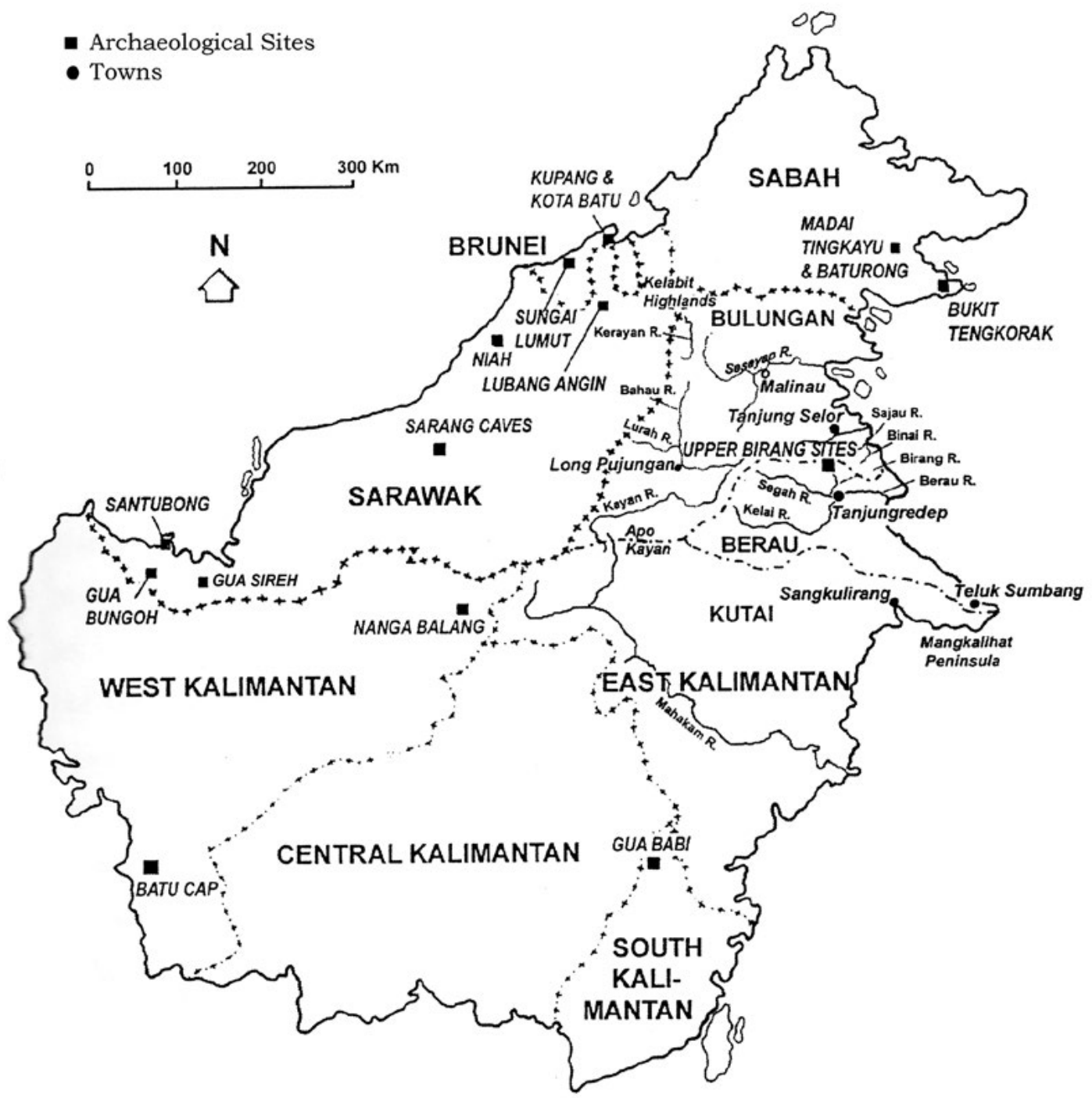

Figure 6.1 Map of Borneo illustrating the location of the Upper Birang and other key archaeological sites across the island.

Source: After Arifin 2004: 9.

Liang Gobel was the smallest rock shelter ( $8 \mathrm{~m}$ long by $5 \mathrm{~m}$ wide) excavated in this study. It is situated on a $5 \mathrm{~m}$ high limestone wall, at $205 \mathrm{~m}$ above sea level (asl) and just a few metres from a path that leads to the site of Lubang Payau, no more than a few hundred metres away. A test pit $(1 \mathrm{~m} \times 2 \mathrm{~m})$ labeled LGB/TP was excavated in the middle of the site. It possessed one unit split into three layers, consisting of loose brown ashy silts. Combined, the total depth of deposit was no more than $0.2 \mathrm{~m}$. The excavations produced a small number of earthenware sherds, some lithics and some vertebrate and invertebrate remains.

Lubang Payau is a commercial bird's nesting cave with two tunnels leading to an underground river. The cave is situated at $206 \mathrm{~m}$ asl and has a chamber that covers approximately $10 \mathrm{~m} \mathrm{x} 20 \mathrm{~m}$ with a flat platform at the entrance, before gradually sloping towards the interior. Two test pits were excavated in the middle of the entrance gallery. Trench LPY/C3 was the closest of the trenches to the cave entrance. It was excavated at the highest point in the cave floor and measured $1 \mathrm{~m} \mathrm{x} 2$ $\mathrm{m}$ with the long axis orientated east-west. This trench produced the most informative sequence of occupation in Lubang Payau, extending to a total depth of $1.6 \mathrm{~m}$. LPY/C3 could be divided 
into three units consisting of sandy silts (Unit I) overlying the silts and silty clays of Units II and III. Unit I had a depth of $c a .0 .4 \mathrm{~m}$ and consisted of a sequence of thin deposits that contained earthenware pottery. Unit II comprised two stratigraphic layers of total depth $c a .0 .45 \mathrm{~m}$, with the upper containing the greatest density of archaeological materials, and concentrations diminishing towards the base of the unit. The upper of the two stratigraphic layers assigned to Unit III (total depth $c a .0 .7 \mathrm{~m}$ ) was really an extension of Unit II, but contained fewer cultural remains. The basal deposits were devoid of any evidence of human activity. Earthenware pottery was only recorded in the upper layers (Unit I) along with three shell scrapers manufactured from the mangrove bivalve Geloina erosa, most of the animal bones and shell. Stone artefacts were recovered throughout the archaeological sequences but with a concentration within Unit II. Although isolated human bones were recovered, no distinctive burials were identified.

Trench LPY/D5 was situated towards the interior of the cave, $c a .2 \mathrm{~m}$ to the northeast of Trench LPY/C3, and measured $2 \mathrm{mx} 2 \mathrm{~m}$. LPY/D5 had a total depth of $0.5 \mathrm{~m}$, but only the upper $0.3 \mathrm{~m}$ contained any archaeological materials (below this was sterile sandy silts). Within this single activity unit all but Spit 6 possessed earthenware pottery, with lithics, animal bone and shell to the base.

Three samples were dated from Lubang Payau using radiocarbon, one on charcoal and two on freshwater shell, all from LPY/C3 (Table 6.2). The two dates, one on charcoal, the other on freshwater shell, both from Spit 6 (Unit II), emphasise the problem of potential 'old carbon' uptake during the construction of the calcium carbonate shell in limestone karst regions (ANU-11152 and ANU-11260). This conclusion is supported by Bellwood (1988: 120) and Datan (1993: 17), who have suggested that at Madai Cave in Sabah and Gua Sireh in Sarawak, respectively, freshwater shell dates were approximately 500 years older than those on charcoal from the same stratigraphic layers. Spriggs (1989: 598) has argued that 'old carbon' in shell can result in unpredictable ages, potentially greater than 1,500 years older than those recorded for charcoal from corresponding deposits. In the case of the Upper Birang samples the error is probably even greater than this. For example, in Kimanis trench KMS/C4, a freshwater shell dated to 13,860 \pm 180 (ANU-11258) was derived from the same layer (Spit 24, 105-110 cm below the surface) as charcoal dated to $10,030 \pm 260 \mathrm{BP}$ (ANU-11150) suggesting a potential 3,000 year deviation (see Table 6.2). As a result, only the charcoal dates from Lubang Payau and Kimanis are considered reasonably reliable in this study. Therefore, the only trustworthy sample from Lubang Payau is the charcoal from Unit II that produced a date of 5637-5081 cal. BP (ANU-11152). This date implies that pottery was introduced to the region after ca. $5000 \mathrm{BP}$, and that Unit II at Lubang Payau is of similar age to the upper sequence in the same unit at Kimanis (ANU-11148; see below and Table 6.2).

Kimanis is a large cave with an overhang at the entrance that forms a rock shelter. It is located at $2^{\circ} 27^{\prime} 4^{\prime \prime} \mathrm{N} / 17^{\circ} 24^{\prime} 38^{\prime \prime} \mathrm{E}$ and $206 \mathrm{~m}$ asl, about $160 \mathrm{~m}$ west of Lubang Payau. The rock shelter forms a spacious dry area, with its surface sloping slightly to the west, towards the entrance of the cave. The habitable area under the rock shelter covers approximately $22 \mathrm{~m} \times 8 \mathrm{~m}$. Three trenches were excavated.

Test pit KMS/TP, measured $1 \mathrm{~m}^{2}$ and was located furthest east and the greatest distance from the cave entrance. The five stratigraphic deposits were divided into two cultural units (Units I and II). Unit I consisted of several layers of brown or yellowish-brown ashy soil totaling between $0.5 \mathrm{~m}-0.7 \mathrm{~m}$ thick. This unit contained earthenware sherds, substantial amounts of bat bone, some stone artefacts, and damar. The lowest excavated layer of Unit II (recorded as Layer E) was excavated to between $0.4 \mathrm{~m}$ and $0.7 \mathrm{~m}$ depth. Excavation ceased when a flexed burial was encountered at $1.3 \mathrm{~m}$ below modern ground surface. Layer E contained some animal bone and shell but no earthenware pottery. 
Table 6.2 A list of the radiocarbon dates from Lubang Payau and Kimanis.

\begin{tabular}{|l|l|l|l|l|l|}
\hline Square/Spit & Unit/Depth (cm) & Material & Lab No. & $\begin{array}{l}\text { Conventional } \\
\text { Age (BP) }\end{array}$ & $\begin{array}{l}\text { Calibrated Date (cal.BP) 0xCal 4.2/ } \\
\text { IntCal 13 }\end{array}$ \\
\hline LPY/C3 Spit 6 & Unit II/ 25-30 & Charcoal & ANU-11152 & $4610 \pm 110$ & $5637-5081(92.4 \%) / 5069-5026(3 \%)$ \\
\hline LPY/C3 Spit 6 & Unit II/ 25-30 & $\begin{array}{l}\text { Freshwater } \\
\text { shell }\end{array}$ & ANU-11260 & $13,100 \pm 140$ & Not calibrated \\
\hline LPY/C3 Spit 23 & Unit III/ 110-115 & $\begin{array}{l}\text { Freshwater } \\
\text { shell }\end{array}$ & ANU-11261 & $17,730 \pm 250$ & Not calibrated \\
\hline KMS/C4 Spit 8 & Unit I/ 35-40 & Charcoal & ANU-11311 & $1270 \pm 240$ & $1685-776(94.1 \%) / 1746-1697(1.3 \%)$ \\
\hline KMS/C4 Spit 11 & Unit II/ 50-55 & Charcoal & ANU-11148 & $4650 \pm 90$ & $\begin{array}{l}5639-5308(79.8 \%) / 5240-5105(13.5 \%) \\
/ 5302-5282(1.3 \%)\end{array}$ \\
\hline KMS/C4 Spit 20 & Unit II/ 98 & Charcoal & ANU-11149 & $8840 \pm 250$ & $10,638-9452(95.1 \%)$ \\
\hline KMS/C4 Spit 24 & Unit III/ 105-110 & Charcoal & ANU-11150 & $10,030 \pm 260$ & $\begin{array}{l}12,582-11,116(91.4 \%) / 11,017-10,843 \\
(3.7 \%)\end{array}$ \\
\hline KMS/C4 Spit 24 & Unit III/ 105-110 & $\begin{array}{l}\text { Freshwater } \\
\text { Shell }\end{array}$ & ANU-11258 & $13,860 \pm 180$ & Not calibrated \\
\hline KMS/C4 Spit 34 & Unit III/ 155-160 & Charcoal & ANU-11151 & $11,270 \pm 220$ & $13,543-10,774(94.7 \%)$ \\
\hline KMS/C4 Spit 59 & Unit V/ 280-285 & $\begin{array}{l}\text { Freshwater } \\
\text { shell }\end{array}$ & ANU-11259 & $23,630 \pm 480$ & Not calibrated \\
\hline
\end{tabular}

Source: Following Arifin (2004: 104), except the recalibration using 0xCal vers.4.2 (Bronk Ramsey 2009) IntCal 13 (Reimer et al. 2013).

Trench KMS/C4 was located $1.5 \mathrm{~m}$ west of KMS/TP and $6 \mathrm{~m}$ east of KMS/C8 in the rock shelter, relatively close to the south wall. The trench measured $1 \mathrm{~m} \times 2 \mathrm{~m}$ with the long axis orientated north-south and was excavated to a maximum depth of $3 \mathrm{~m}$ below modern ground level. At $c a .1 .5 \mathrm{~m}$ depth a flexed burial was uncovered in the northern portion of the trench, and only the southern half was excavated to rock fall. Nine layers of deposit varying in colour and texture from dark brown ashy silt to reddish-yellow ashy silt could be divided into five activity units (Figure 6.2). Unit I was the only phase of activity to contain pottery. The preceding Unit II $(0.5 \mathrm{~m}-1.05 \mathrm{~m})$ contained relatively few animal bones and a considerable amount of roof collapse. Unit III $(1.05 \mathrm{~m}-1.6 \mathrm{~m})$ produced by far the greatest number of stone tools, animal bones and molluscs, reflecting the most intensive occupation of the site. Unit IV (1.6 m-2 m) possessed fewer vertebrate remains and stone artefacts than Unit III, but still relatively high concentrations of shells. Unit $\mathrm{V}$ was excavated to a depth of $2.95 \mathrm{~m}$ before large rock fall finally prevented deeper investigation. This unit contained much fewer animal bones, lithics and shells than the overlying units, but several notable lenses of ash.

All seven radiocarbon dates for Kimanis are from KMS/C4. Excluding the freshwater shell dates, the remaining five charcoal assays suggest occupation from at least the end of the glacial period at $c a .13,000$ cal. BP, and perhaps considerably earlier based on the freshwater shell date of

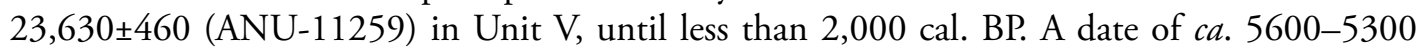
cal. BP from Unit II indicates that the introduction of pottery certainly post-dates this date. If the Unit I date of 1685-776 cal. BP (ANU-11311) is considered representative, pottery might not have been introduced to the region until within the last 2,000 years. 


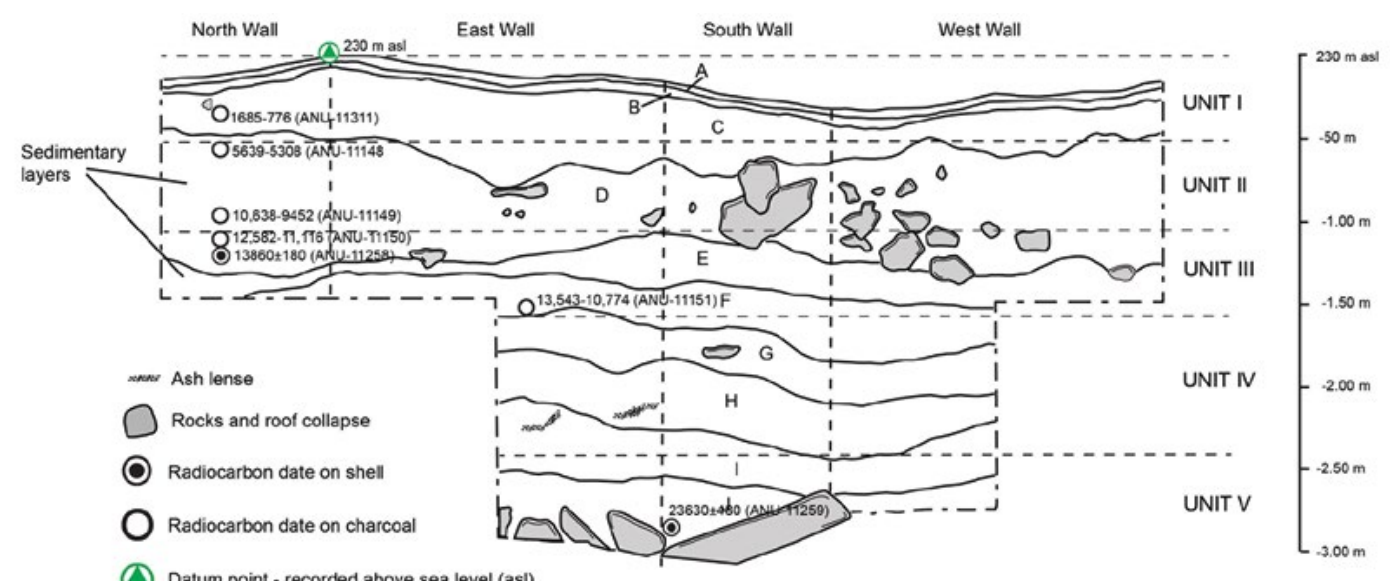

Datum point - recorded above sea level (asl)

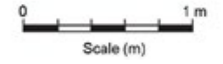

Figure 6.2 An illustration of the four walls of Trench KMS/C4 showing the different archaeological layers and units excavated, and the approximate locations of radiocarbon dates.

Source: After Arifin 2004: 85; the dates have been recalibrated using 0xCal vers.4.1 (Bronk Ramsey 2009) IntCal.13 (Reimer et al. 2013).

Trench KMS/C8 measured $1 \mathrm{~m} \times 2 \mathrm{~m}$ and was dug to a depth of $1.3 \mathrm{~m}$. Two units with layers of brown and yellowish-brown silts with ash very similar to those recorded in KMS/C4 were identified. Unit I was $0.5 \mathrm{~m}$ deep and was the only phase of activity to contain pottery, with relatively small amounts of animal bone, stone artefacts and invertebrates. Unit II was excavated to a maximum depth of $1.3 \mathrm{~m}$. This phase of activity produced higher concentrations of vertebrate and invertebrate remains than Unit I, as well as sizable amounts of roof collapse.

As Kimanis produced the richest archaeological record with the greatest temporal range, the following discussion will be heavily weighted towards interpretation of this site, with a lesser focus on Liang Gobel and Lubang Payau.

\section{Subsistence strategies}

\section{Vertebrate remains}

Vertebrate remains from all the Upper Birang archaeological sites are very fragmented. This is typical for cave sites in Southeast Asia and probably results from a combination of anthropic taphonomic processes such as butchery and bone breakage for marrow extraction, considerable human foot traffic within the confines of cave entrances and rock shelters, and natural processes like roof collapse (see Piper and Rabett 2016). As a result the majority (greater than 50 per cent) of small bone fragments remain anatomically and taxonomically unidentified (Table 6.3). Of the remainder, levels of taxonomic identification are dependent on a number of variables that include the degree of preservation, survival of diagnostic anatomical features and the complexity and diversity of the family and/or genus the skeletal element is likely to belong to. For example, the Malay tapir (Tapirus indicus) is the sole survivor of its genus in the Late Pleistocene of SEA, and any bone fragments attributable to the tapir almost certainly come from this species. In contrast, the complex diversity of rodent murids (Muridae) makes it difficult to confidently differentiate the majority of anatomical elements recovered from the archaeological record beyond family level (Tables 6.4 and 6.5). 


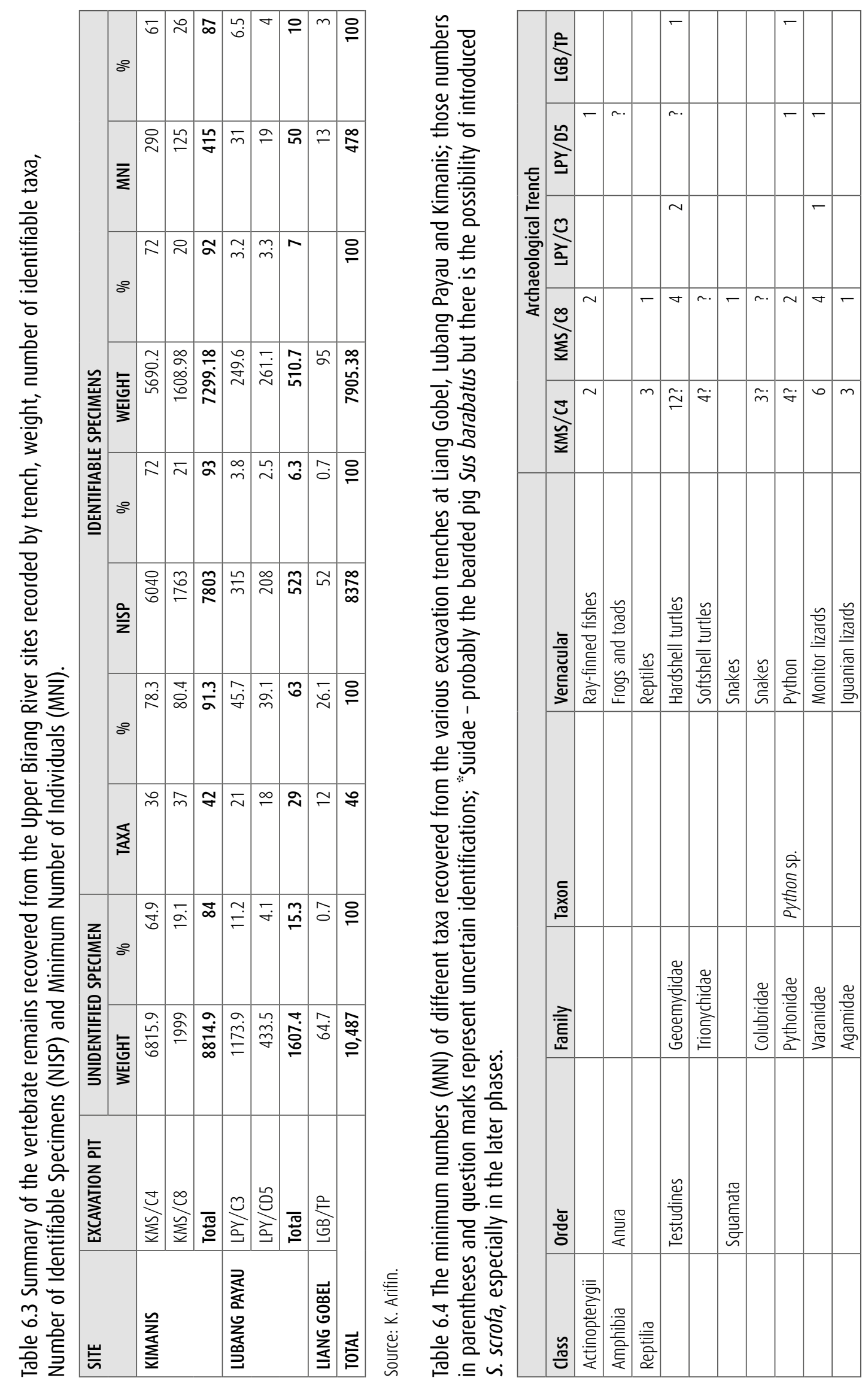




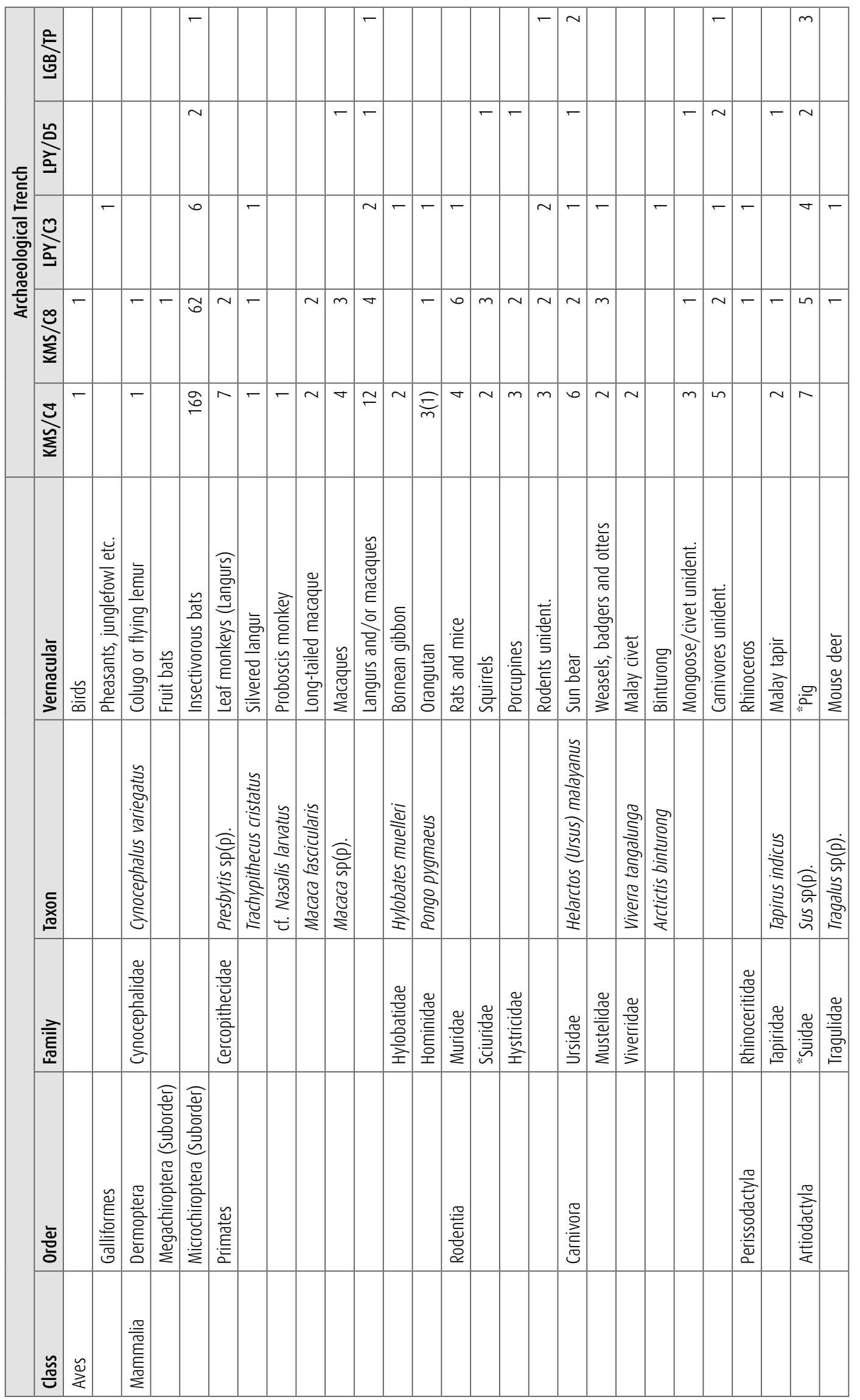



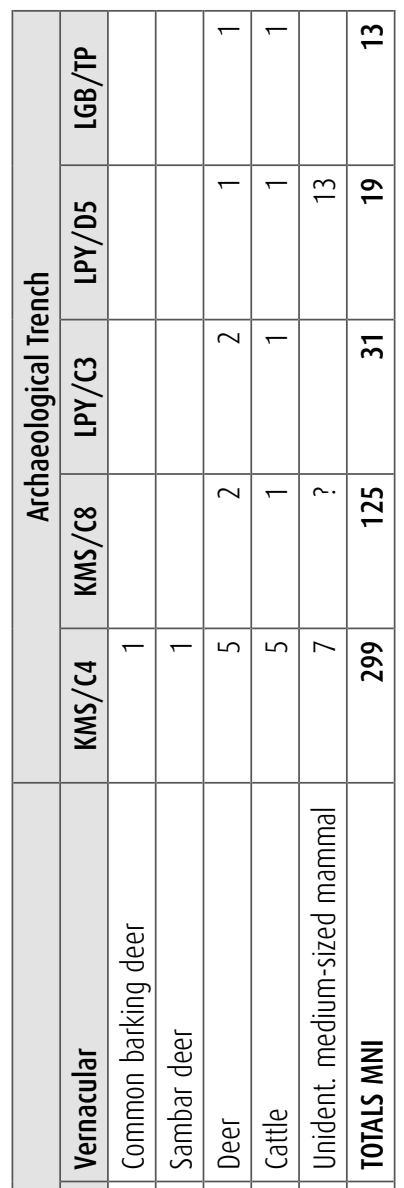

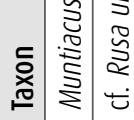

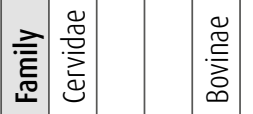

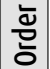

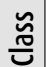

厸

产

듕ำ

㐱

늘

总製

응 흉

จ

$\stackrel{و}{\equiv}$

绶

든 ㅎ̆ํ

형 흔

वे

बㄴ

莃

등

离

害兽

玄芒

至.듬

言总

음 들

○

艺言

ฮั ฐ

氖至 巳

䒘峰

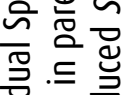

글 든

है.

怘

है을

艺苍

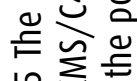

능 는

兄就

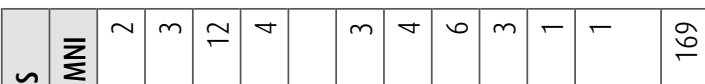
言

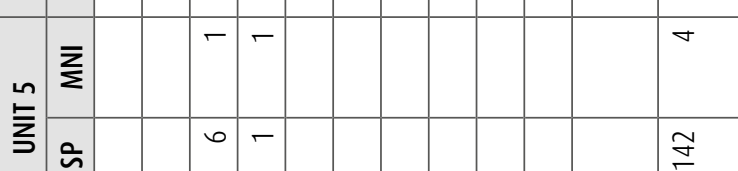

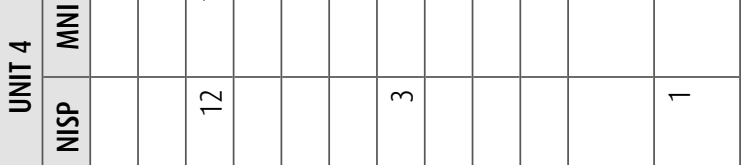

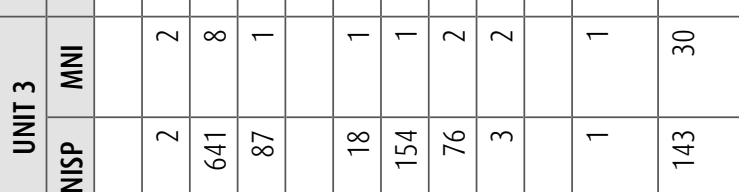

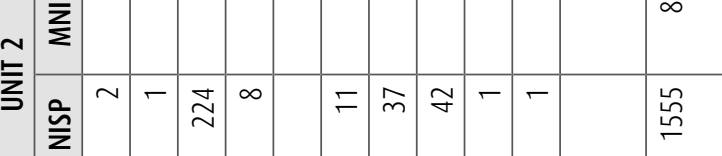

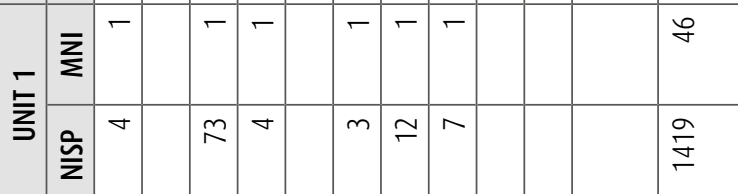

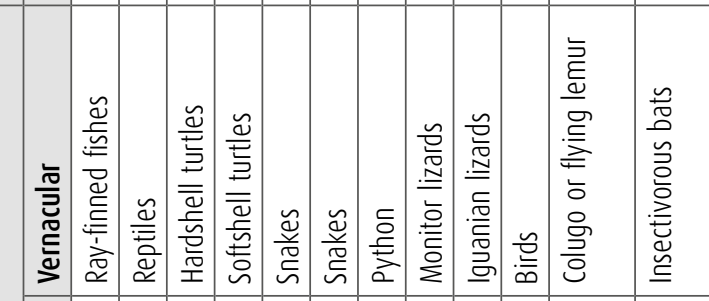

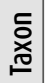

$\frac{\sqrt{2}}{\frac{2}{2}}$

空

妾

高

\begin{tabular}{|c|c|c|c|c|c|c|c|c|}
\hline & 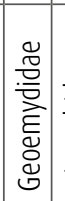 & 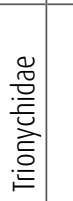 & 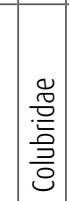 & 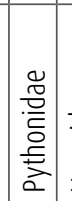 & 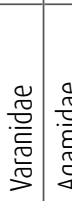 & 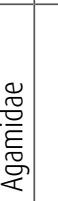 & 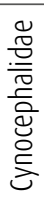 & \\
\hline & 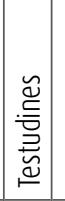 & $\begin{array}{l}\frac{f}{a} \\
\hat{c} \\
\bar{a} \\
\bar{\jmath}\end{array}$ & $\begin{array}{l}0 \\
0 \\
0 \\
\\
\\
\end{array}$ & & & & 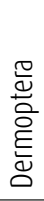 & 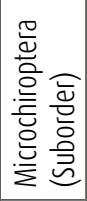 \\
\hline
\end{tabular}

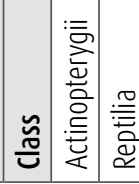

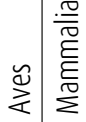




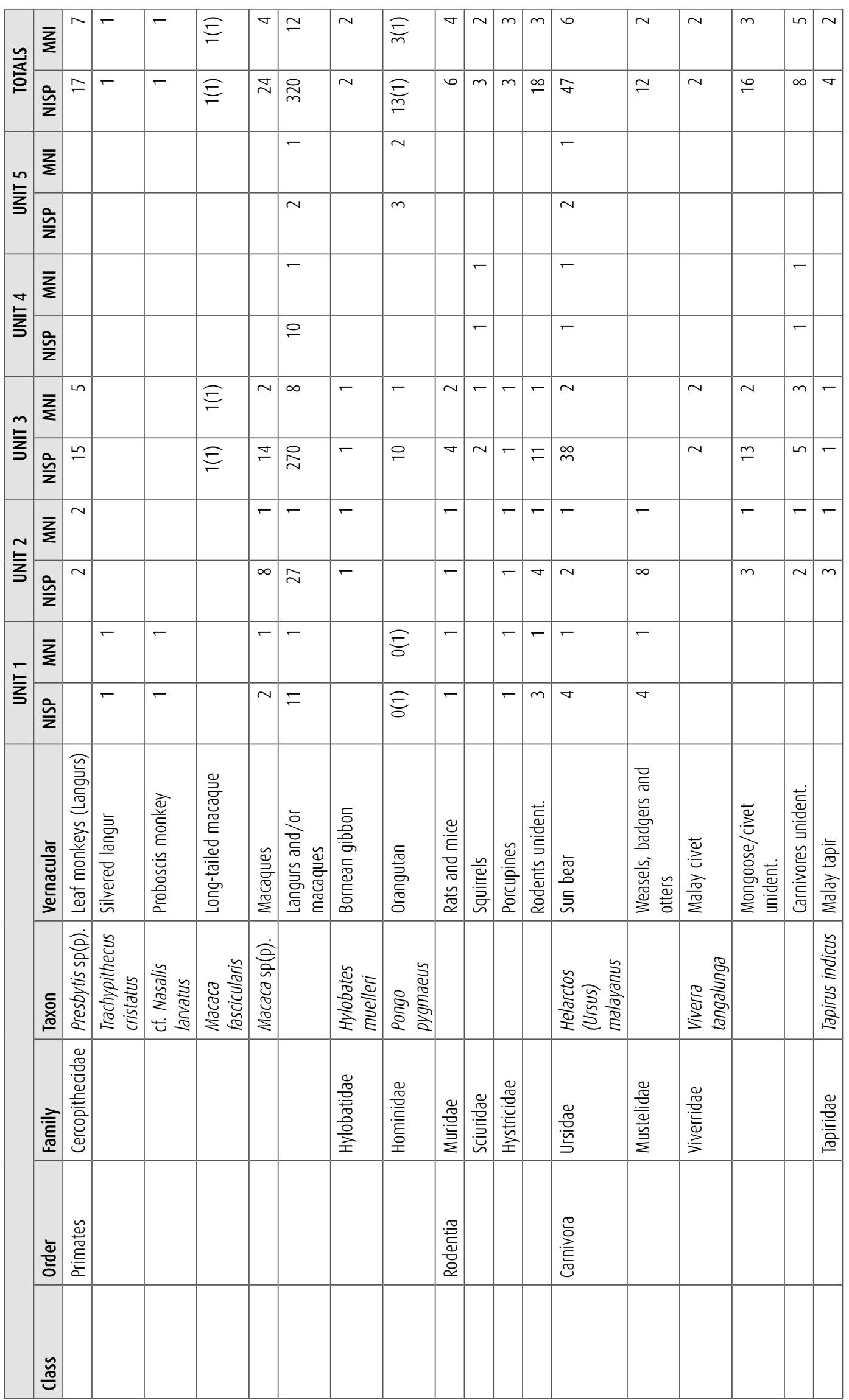




\begin{tabular}{|c|c|c|c|c|c|c|c|c|c|}
\hline$\simeq$ & $\sum_{\Sigma}$ & 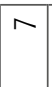 & - & - & Ln & in & $\sim$ & సे & $\stackrel{m}{m}$ \\
\hline 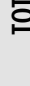 & $\frac{\bar{n}}{z}$ & 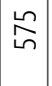 & $\sim$ & - & $\stackrel{m}{\digamma}$ & $\stackrel{H}{n}$ & 흐 & 옹 & $\stackrel{\stackrel{\curvearrowright}{\sim}}{\stackrel{\infty}{~}}$ \\
\hline & $\sum_{\Sigma}$ & - & & & - & & - & $m$ & $a$ \\
\hline 立 & $\frac{\bar{n}}{z}$ & & & & $\sim$ & & $\sim$ & $\stackrel{R}{1}$ & $\stackrel{\infty}{\sim}$ \\
\hline & $\sum_{\Sigma}$ & - & & & - & - & - & $=$ & 으 \\
\hline 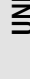 & $\frac{\grave{n}}{z}$ & $\stackrel{m}{=}$ & & & in & $\nabla$ & 은 & 5 & 8 \\
\hline$m$ & $\bar{z}$ & $m$ & $\tau$ & - & $\sim$ & $\sim$ & $m$ & $\alpha$ & $\widetilde{\sigma}$ \\
\hline 当 & $\underline{\grave{n}}$ & 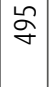 & $\sim$ & - & ஃ & f & 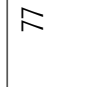 & $\stackrel{\sim}{\underset{N}{*}}$ & బ̊ \\
\hline 工 & $\sum_{\Sigma}$ & - & & & - & - & - & $\stackrel{0}{\rightleftharpoons}$ & $\stackrel{\infty}{\sim}$ \\
\hline$\underline{\Sigma}$ & $\frac{\bar{n}}{\bar{z}}$ & 年 & & & $\circ$ & $r$ & $a$ & 吕 & \& \\
\hline$E$ & $\bar{\Sigma}$ & - & & & . & - & - & 吕 & $\stackrel{2}{2}$ \\
\hline z & $\frac{\grave{n}}{z}$ & $\simeq$ & & & & $m$ & $m$ & $\begin{array}{l}\stackrel{\infty}{\circ} \\
\stackrel{2}{\circ}\end{array}$ & 守 \\
\hline & 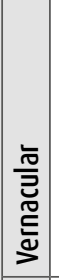 & $\frac{9}{2}$ & 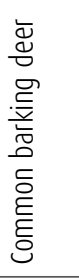 & 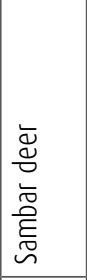 & $\begin{array}{l}\grave{\Xi} \\
\check{\Xi}\end{array}$ & 总 & 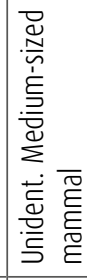 & 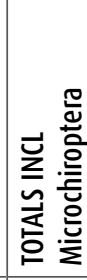 & 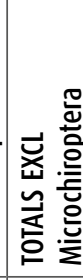 \\
\hline & 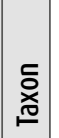 & $\begin{array}{l}\dot{\vec{a}} \\
\overline{\bar{n}} \\
\tilde{n} \\
\tilde{n}\end{array}$ & 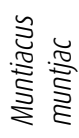 & 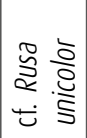 & & & & & \\
\hline & 彥 & 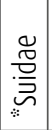 & 离 & & & 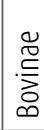 & & & \\
\hline & 彥 & 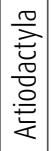 & & & & & & & \\
\hline & 岕 & & & & & & & & \\
\hline
\end{tabular}


Although a systematic analysis of butchery was not conducted on the bone assemblages from the Upper Birang sites, the presence of burnt bones and the strong similarities between these bone accumulations and those recovered from sites such as Niah where a thorough examination of human exploitation was undertaken (see Piper and Rabett 2016) strongly suggests that most, if not all, the remains of large and medium-sized mammals and reptiles were accumulated by people. Some animals, especially bats and rodents may have died in, or been brought back into, the caves and rock shelters by carnivores. The vertebrate assemblages include a diverse range of taxa that occupied a variety of ecological niches. By far the most abundant taxa recorded (MNI) in the Upper Birang sites were insectivorous bats, particularly at Kimanis. Although many species of bat are trogloxenes and would have inhabited the dark recesses of the caves and probably represent part of the caves' natural death assemblage, some could also have been hunted. For example, Stimpson (2016) identified the hunting of particular species of at Niah Caves, Sarawak from at least 40,000 years ago. However, close examination of the spatial distribution of bats compared to the main animal bone accumulations at Kimanis indicates that the Chiroptera bones amassed in the later phases of activity (Units I and II), whereas large and intermediate-sized mammals and reptiles were recovered primarily from Unit III. This perhaps indicates natural rather than anthropic modes of accumulation for bats. In fact, if bats are excluded in KMS/C4, approximately 75 per cent of all mammals and reptiles were recorded in Unit III (Table 6.5) and probably date to the terminal Pleistocene, between 13,000-11,000 cal. BP.

A broad diversity of arboreal and terrestrial mammals and reptiles appear to have been hunted or captured during the terminal Pleistocene and early Holocene at Kimanis and Lubang Payau, including a variety of carnivores, monitor lizards (Varanus sp(p).), softshell (Trionychidae) turtles, sun bear (Helarctos (Ursus) malayanus), cattle (Bovinae) and tapirs (Tapirus indicus). Large deer, probably Sambar appears to have been relatively common in the environments of the Upper Birang. However, in KMS/C4 pigs (Sus cf. barbatus), primates and hardshell turtles (Geoemydidae) dominate the hunted vertebrate communities in the terminal Pleistocene. Several primates are represented in the assemblages including habitual arboreal taxa such as the Bornean gibbon (Hylobates muelleri) and the orangutan (Pongo pygmeaus). The most common primates though are the macaques (Macaca sp(p).) and leaf monkeys (Presbytis sp(p).).

The presence of both the silvered langur (Trachypithecus cristatus) and proboscis monkey (Nasalis larvata) in Unit I are intriguing. Both these species are most commonly found in coastal mangrove swamp forests or peat forests, though they do also frequent riverine forests (Meijaard et al. 2008). Indeed, Arifin (2004: 127) reports that the proboscis monkey is the most common species of primate encountered along the Birang River today.

\section{Osseous artefacts}

Bone artefacts were not common in the Upper Birang sites only being found in the upper units at Kimanis $(\mathrm{N}=7)$ and Lubang Payau $(\mathrm{N}=5)$. Provisional analysis suggests they were all manufactured from longitudinally split fragments of mammalian long bone. These had then been modified through oblique grinding to produce points (unipoint or bipoint) or spatulae (see Rabett 2002 for terminology). Preliminary observations (no systematic microscopic analysis was undertaken) indicated that some artefacts possessed smooth and/or polished surfaces near the tip suggesting use-wear perhaps as piercing implements or awls. Generally speaking though, the small overall number of bone artefacts recovered from within large bone accumulations would perhaps indicate that other organic materials such as bamboo, rattan and palm as well as stone provided substantially more raw materials for artefact production than bone. 
The osseous artefacts from Kimanis were all recovered from below the ceramic horizons in deposits with abundant animal bones and shell and likely date to the terminal Pleistocene/ early Holocene. In Lubang Payau bone implements were recorded from within and below the ceramic levels.

\section{Invertebrates and shell artefacts}

In all sites, the mollusc assemblages were dominated by the freshwater snails Brotia sp. (Table 6.6). These were present in small numbers from the basal deposits of KMS/C4 to contemporary ground surface in Lubang Payau. In trenches KMS/C4 and KMS/C8, Brotia sp. accounted for 95.6 per cent of the total MNI counted (6399/287; Table 6.7). Trench KMS/C4 indicated that the densest accumulations were within Units III and IV, and associated with the largest concentrations of animal bone dated to $c a$. 13,000-11,000 cal. BP. A high proportion of the shells were missing the apex, a pattern of deliberate human breakage of the natural vacuum within the gastropod that enables easier removal of the fleshy body.

In LPY/C3, the greatest numbers of Brotia sp. were concentrated in Unit II and the basal deposits of Unit I, just below a radiocarbon date of 5637-5081 cal. BP (ANU-11152). This suggests that the majority of shells were collected in the mid-Holocene. The accumulations peter out below layers containing pottery. In contrast, Brotia sp. was common throughout the deposits of LPY/D5, to modern surface. Overall, this suggests differential periods of intermittent collection and shell dumping within these two caves' entrances, but the practice of freshwater snail consumption continued from the late Pleistocene through the Holocene. Brotia sp. can be found close to the archaeological sites in the Birang River and are still being eaten by the contemporary inhabitants of the region today.

Several other freshwater, terrestrial and arboreal snails likely found within the local environments around the caves were identified including Paludomus sp(p)., Cycloporids and Amphidromus sp(p). Of more interest is the small number of 'exotic' marine Mollusca identified in the assemblages (Tables 6.6 and 6.7). The coast is now some $60 \mathrm{~km}$ in a straight line from the Upper Birang sites, and even if sea level change potentially increased (in the Pleistocene) or shortened (during the Holocene high sea stand) that gap, it would still mean transportation over a considerable distance from coast to cave. The species collected and returned to the sites also derive from different ecological zones. For example, Cypraea spp. (cowry shell) is commonly found in shallow/deep marine environments, whereas the bivalve Geloina erosa and gastropods Terebralia and Telescopium inhabit mangrove swamps.

At Kimanis cowry shells were found throughout the ceramic and upper preceramic layers. The oldest specimen was from Unit III and potentially associated with a date of 12,582-11,116 cal. BP (ANU-11150). The dorsal surfaces of the shells had been removed and the edges ground flat, and probably strung for ornamental purposes. It was clear from the fragmentary remains of the Geloina erosa valves that they had been modified and probably used as tools. Close examination of the margins indicated that they had either been retouched and/or showed evidence of use wear (Figure 6.3). It is possible that these artefacts were used for either scraping or cutting functions. Edge damage and step fractures indicate that the shell tools might have been used on relatively hard materials, and possibly over a considerable length of time. Shell implements were primarily found in ceramic-bearing deposits, but the deepest and potentially oldest specimen was recovered from Kimanis Unit II in association with a date of 10,638-9452 cal. BP (ANU-11149). 


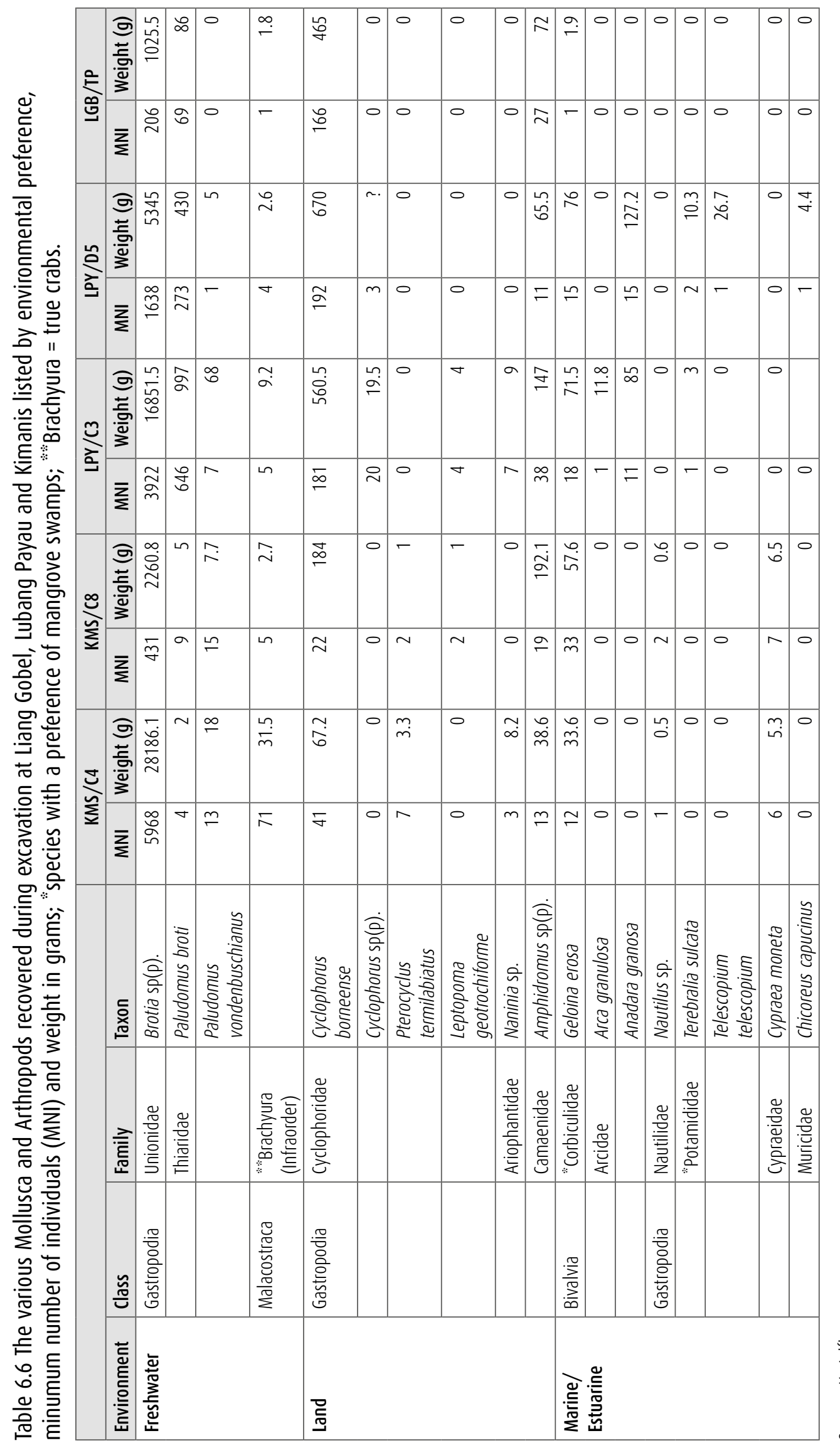

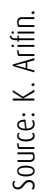




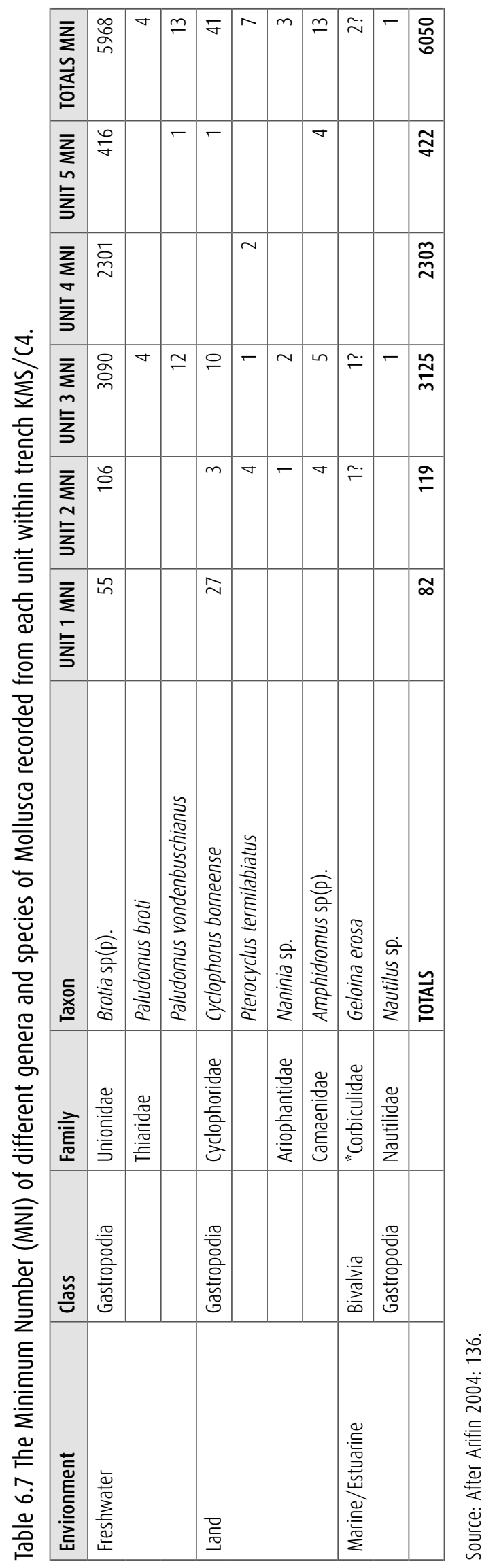



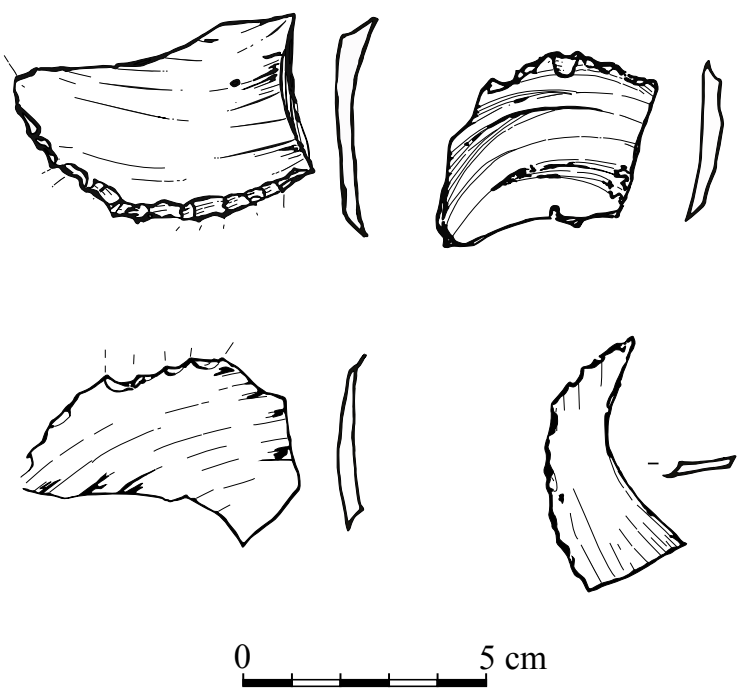

Figure 6.3 An example of retouched fragments of shell artefact from the Upper Birang River sites. Source: After Arifin 2004: 248.

\section{Stone artefacts}

A total of 1,319 stone artefacts weighing $43 \mathrm{~kg}$ were analysed from the Upper Birang sites. In total, more than 70 per cent of the lithic assemblage came from Kimanis, 27 per cent from Lubang Payau and only 1 per cent from Liang Gobel. Kimanis also produced more than 94 per cent of the stone artefacts by weight. This was primarily due to the number of calcareous sandstone implements manufactured and/or utilised from shattered roof fall from the cave roof.

All three archaeological sites produced stone artefacts manufactured on similar raw materials. Overall they consisted of 42 per cent chert, 16 per cent volcanic rocks, 12 per cent calcareous sandstone and 9 per cent unidentified sedimentary rock, while 5 per cent consisted of miscellaneous microgranodiorite, limestone, crystalline limestone, sandstone, calcareous siltstone, milky quartz and quartzite. There appeared to be little spatial or temporal change in raw material preference or types of tool manufactured throughout the archaeological sequences that might have indicated, amongst other things, technological change. The only exception to this general rule was the introduction of milky quartz artefacts in the upper activity units (Units I and II), coinciding with the first appearance of bipolar flaking (bipolar flakes and cores).

Aside from implements produced on calcareous sandstone, all raw materials must have been derived from somewhere other than the limestone caves in which they were found. Remnant cortex on some artefacts indicated that most, if not all had been manufactured from river pebbles. Observations on the stone within the Upper Birang River close to the archaeological sites showed that the stone in the riverbed close to the rock shelters and cave consisted of small pieces of siltstone. The likelihood is that raw materials for tool production were acquisitioned from further upstream in rivers nearby. 


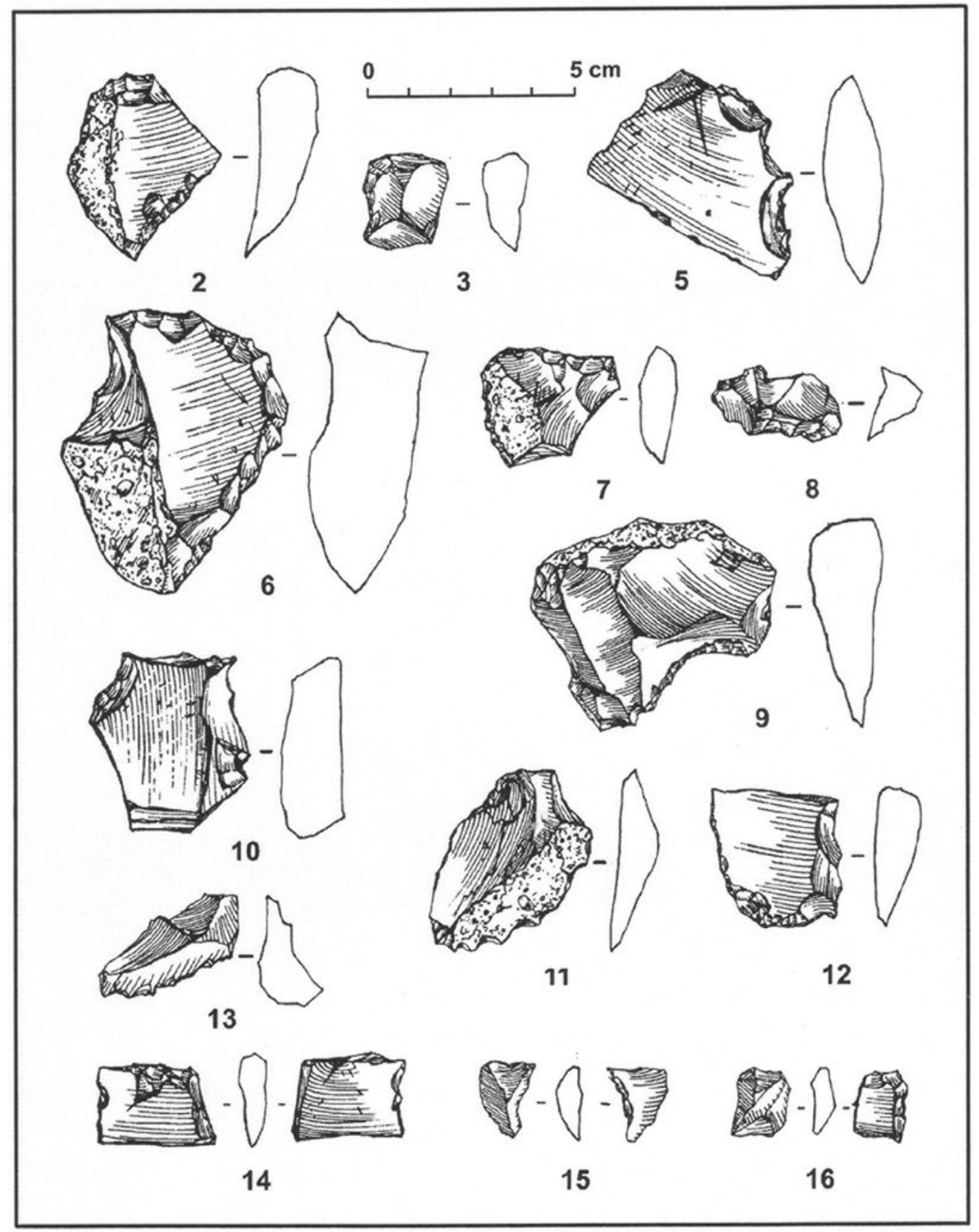

Figure 6.4 Lithic implements from KMS/C4: utilised flakes (2 \& 3), retouched flakes (5 \& 6), and utilised and retouched flakes (7-16).

Source: After Arifin 2004: 443.

Twenty different types of artefact/artefact fragment could be identified, with flakes (37 per cent of the total stone items analysed), followed by shatters (20 per cent), flake fragments ( 15 per cent), flake shatters (10 per cent), and heat shatters (9 per cent) dominating. Other specimens included bipolar flakes, érailure flakes, retouched flakes, retouched cores, unidirectional cores, multidirectional cores, bipolar cores and core fragments. The presence of primary flaking and cores suggests that pebble reduction and artefact production were occurring on site. 


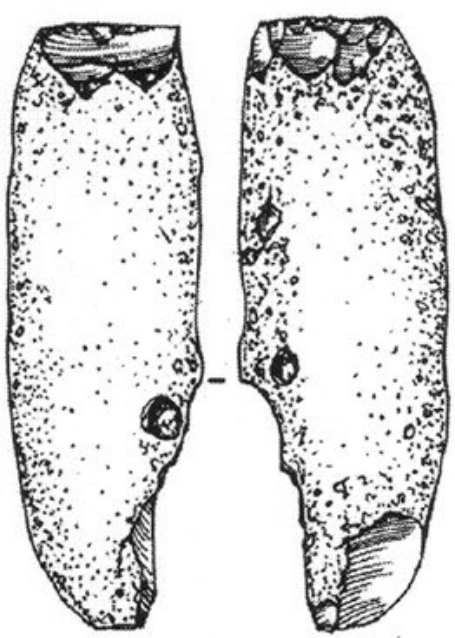

17
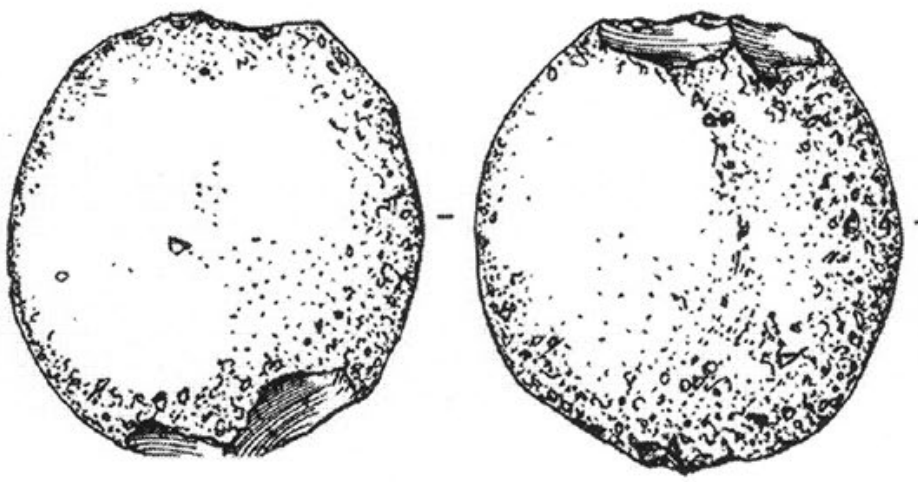

19

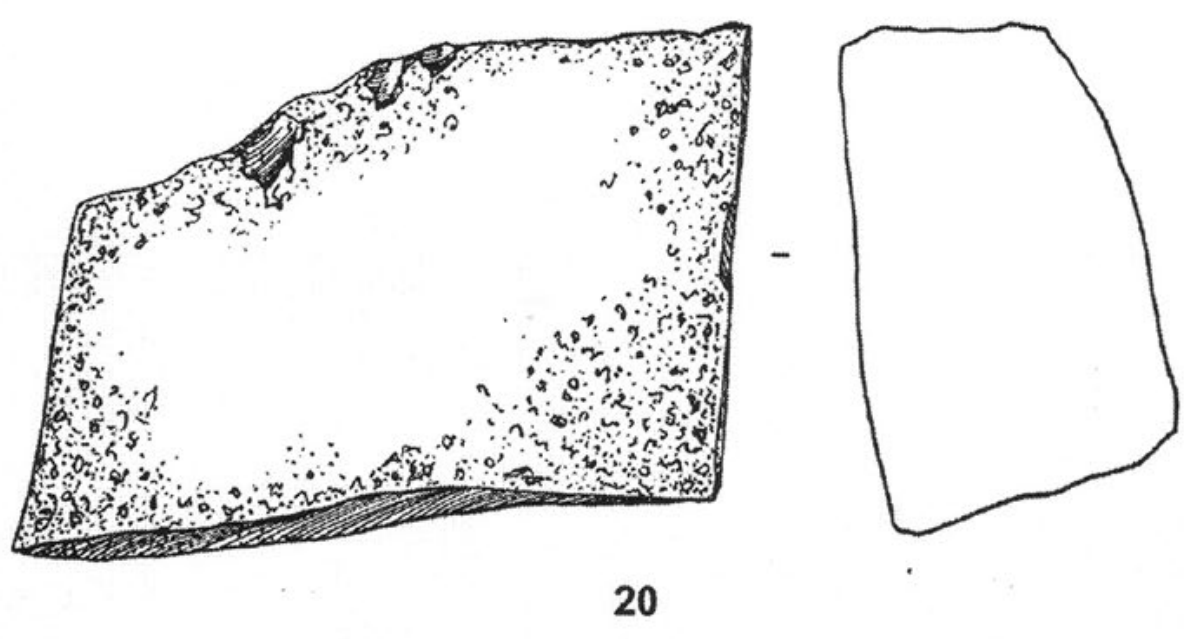

Figure 6.5 Lithic implements from KMS/C4: hammerstone fragments (17 \& 18), hammerstone and grindstone (19), and grindstone fragment (20).

Source: After Arifin 2004: 444.

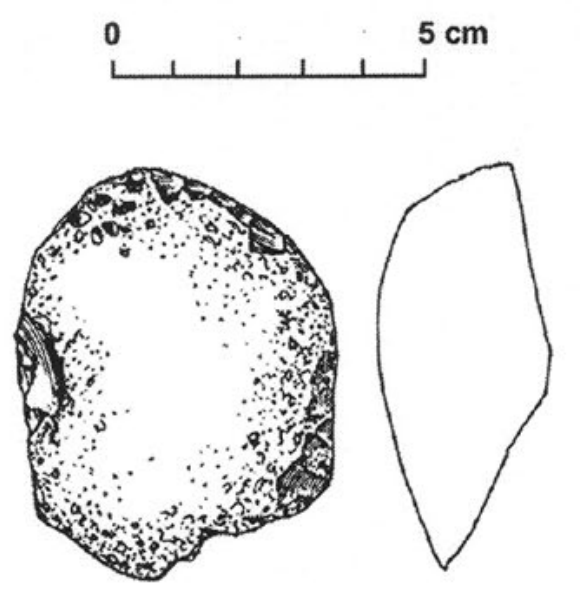

18

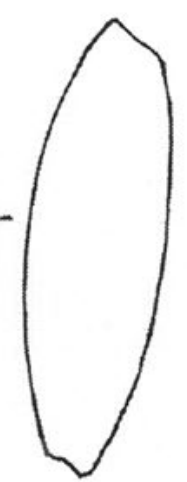


Of these, 41 stone implements were recorded, accounting for just 3 per cent of the total lithic assemblage. Most of these had been produced using the hard hammer technique flaking pebble cores. Represented were lost or discarded utilised flakes, utilised and retouched flakes, retouched flakes, retouched cores, hammerstones and hammerstone fragments, and grindstone fragments (Figures 6.4 and 6.5).

In total, 13 different types of activity involving stone tool use could be discerned within the lithic assemblages (Table 6.8). For example, use-wear analysis showed that several implements possessed use scars with bending initiation and step terminated fractures, as well as edge rounding between use fractures, characteristic of scrapers used on resistant materials, such as hard wood or bone (Kamminga 1982: 69). The existence of highly reflective silica polish on some implements perhaps indicates utilisation in processes such as the stripping rattan, palm leaves or bamboo, or the manufacture of basketry. In some instances, non-silica polish on the working edge of implements suggested functional use in activities such as hide working or butchery. On one artefact, the presence of bending fractures is reminiscent of damage reported by Kamminga (1982: 34) to have resulted from cutting fresh meat. Other artefacts have concave working edges suggestive of tools used to produce and/or maintain cylindrical objects, such as wooden shafts.

Table 6.8 Activities undertaken in Upper Birang sites according to the evidence of lithic items.

\begin{tabular}{|c|c|c|}
\hline No. & Activity & Categories of artefacts \\
\hline \multirow[t]{3}{*}{1} & \multirow[t]{3}{*}{ Non-specific stone knapping } & Flake or flake fragment \\
\hline & & Core or core fragment \\
\hline & & Flake shatter \\
\hline \multirow[t]{3}{*}{2} & \multirow[t]{3}{*}{ Bipolar flaking } & Bipolar flake \\
\hline & & Bipolar core \\
\hline & & $\begin{array}{l}\text { Utilised and retouch flake with one of the lateral } \\
\text { margins removed by bipolar blow }\end{array}$ \\
\hline 3 & Pressure flaking? & Hammerstone fragment \\
\hline \multirow[t]{3}{*}{4} & \multirow[t]{3}{*}{ Retouching } & Retouched flake \\
\hline & & Retouched core \\
\hline & & Utilised and retouched flake \\
\hline 5 & Backing retouch & Utilised and retouched flake \\
\hline \multirow[t]{2}{*}{6} & \multirow[t]{2}{*}{ Light duty hammering } & Hammerstone \\
\hline & & Hammerstone fragment \\
\hline \multirow[t]{4}{*}{7} & \multirow[t]{4}{*}{ Use and discard of non-specific implement } & Utilised flake \\
\hline & & Retouched flake \\
\hline & & Retouched core \\
\hline & & Utilised and retouched flake \\
\hline \multirow[t]{2}{*}{8} & \multirow{2}{*}{$\begin{array}{l}\text { Use and discard of implement for maintenance activity } \\
\text { such as making wooden object }\end{array}$} & Utilised flake \\
\hline & & Utilised and retouched flake \\
\hline \multirow[t]{2}{*}{9} & \multirow{2}{*}{$\begin{array}{l}\text { Use and discard of implement for light duty activity, } \\
\text { such as butchering and cutting }\end{array}$} & Utilised flake \\
\hline & & Utilised and retouched flake \\
\hline 10 & $\begin{array}{l}\text { Use and discard of implement for stripping palm leaves, } \\
\text { bamboo or rattan to make mat or basketry }\end{array}$ & Utilised flake \\
\hline 11 & $\begin{array}{l}\text { Use and discard of grindstone for ochre grinding } \\
\text { and other material }\end{array}$ & Grindstone fragment with ochre stain \\
\hline 12 & Use and discard of implement with ochre stain & Retouched flake \\
\hline 13 & Burning activities & Heat shatter \\
\hline
\end{tabular}

Source: After Arifin 2004: 233. 
Amongst the retouched artefacts is a small implement of crystalline quartz from KMS/C4 Unit III dating to the terminal Pleistocene or early Holocene. This specimen had deliberate 'backing' retouch along the left lateral margin, a characteristic of implements that have been hafted (Figure 6.4, no. 16). In fact, the very tiny size of all the crystalline quartz implements might indicate they were specifically designed for hafting. Other evidence of possible hafting includes utilised flakes from KMS/C4 and KMS/C8 Unit I with a black substance coating the artefact surfaces that could represent remnant-hafting mastic. Other implements were more likely handheld, especially between the thumb, index and middle fingers.

Two grindstones, one of white quartzite from KMS/C4 Unit III and the other a fragment of crystalline limestone from Unit II of the same excavation square are notable. The specimen from Unit III was a flattened oval pebble with both surfaces moderately convex and smooth (Figure 6.5, no. 19). Subsequent use as a hammerstone had resulted in the removal of a flake from each end of the artefact. The Unit II specimen was a flat stone that retained a thin layer of ochreous residue in depressions suggesting it was used as a pallet (Figure 6.5, no. 20). These specimens probably date to the terminal Pleistocene and mid-Holocene respectively.

Burnt and heat-shattered stone was a relatively common modification observed in almost all the stone assemblages from the three archaeological sites.

\section{Pottery}

All the ceramics recorded from the Upper Birang archaeological sites were within the upper units of excavation. Two dates of 5637-5081 cal. BP (ANU-11152) from LPY/C3 and 5639-5308 cal. BP (ANU-11148) from Kimanis indicate that all pottery was derived after the mid-sixth millennium BP. If a date of 1685-776 cal. BP (ANU-11311) from within the Unit I potterybearing deposits of Kimanis is considered reliable then the introduction of ceramics to the Upper Birang might not have occurred until after 2,000 years ago.

All the pottery was made by hand through modelling and the use of the paddle and anvil technique. The majority of sherds were plain, but a few (with the greater number at Lubang Payau) possessed simple paddle-impressed, cord-marked or incised decoration (Figure 6.6). Based on rim shapes, diameters, carinations and base fragments, it is likely that most of the pottery consisted of globular cooking pots very similar to ethnographic examples in Sarawak (Morrison 1954-1955; Freeman 1957) and the cooking pots of the Kenyah Lepo' Ké or Apau Ping of Kecamatan Long Pujungan, East Kalimantan (Arifin and Sellato 1999). None of the sherds possessed red-slipped exteriors characteristic of the Neolithic pottery from sites such as Bukit Tengkorak in Sabah (Bellwood 1989).

A few of the potsherds have inclusions of rice husk as temper. This implies that the visitors to the caves and rock shelters of the Upper Birang either belonged to, or had direct or indirect contact with, agricultural communities within the last two millennia or so. 


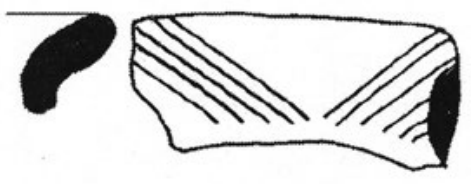

a

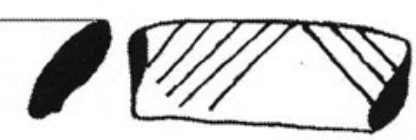

b

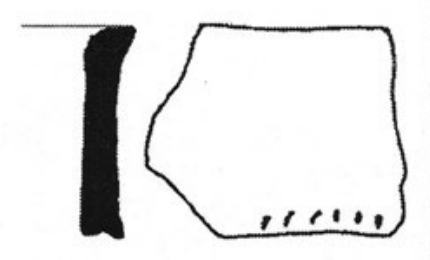

C

Figure 6.6 Incised rim sherds from Lubang Payau.

Source: After Arifin 2004: 257.

\section{Discussion}

Archaeological excavations in the Upper Birang have demonstrated that initial human occupation of this region of East Kalimantan can be dated to the Late Pleistocene. Until recently, Kimanis had the deepest and oldest archaeological record in the region with the earliest reliable date coming from the base of Unit III at 13,543-10,774 cal. BP (ANU-11151). However, the archaeological record extends into Unit $\mathrm{V}$ and perhaps indicates initial colonisation by at least the end of the Last Glacial Maximum.

Kimanis is situated at $c a .200 \mathrm{~m}$ asl and it is likely that the cooler, drier climates that existed at the end of the Pleistocene in Borneo had a significant impact on the local and regional environment (see Bird et al. 2005; Würster et al. 2010). A provisional study of the phytolith samples from Unit $\mathrm{V}$ by Bowdery (in Arifin 2004: 374) seems to support this conclusion, in that a number of (undefined) tree species seem to be absent from the floral record, compared to the later phases of cave sediment deposition, possibly as a result of changes in the levels of forest cover. At Niah, systematic pollen analysis has demonstrated that during the Late Pleistocene there was relatively rapid climate-driven environmental change, from extremes of warm, moist dense tropical rainforest to much cooler climates when a diverse mixture of submontane and lowland woodland predominated within ecological communities with no modern parallels (Hunt et al. 2007; Barton et al. 2013). At Kimanis the presence of arboreal taxa such as leaf monkeys, orangutan and the sun bear in lower Unit IV and Unit $\mathrm{V}$ would suggest that forest cover of some sort was maintained, if only periodically, during the final stages of the Late Pleistocene in the Upper Birang.

Evidence of human activity in the earliest recorded phases at Kimanis is relatively scant and consists of a few stone flakes and flake fragments manufactured primarily from chert. This might indicate that frequentation of the cave was intermittent and over a short duration by small mobile forager groups. In addition to primates the Late Pleistocene foragers appear to have hunted pig and deer, and caught or trapped hardshell turtles. There is no evidence for the persistence of members of the now extinct middle Pleistocene megafauna such as the giant pangolin (Manis cf. sp. Palaeojavanica), a species that was recorded in the $c a .40,000$ BP deposits at Niah (Hoojier 1960; Cranbrook 2000; Piper et al. 2007).

In the upper layers of Unit IV and in Unit III there is a significant increase in density of human activity at Kimanis. This intensification in occupation coincides with dates of 13,543-10,774 cal. BP (ANU-11151) and 12,582-11,116 cal. BP (ANU-11150). A similar pattern of increased cave frequentation and magnitude of habitation at the end of the Pleistocene has been recorded at Niah (Rabett et al. 2013), at Song Terus (Sémah and Sémah 2012) and Song Gupuh (Morwood et 
al. 2008) in Java and at Ille Cave on Palawan (Lewis et al. 2008). It has been argued that this reflects the movement of human populations inland from coastlines as the marine incursion disrupted ecological systems and reduced resource predictability (Piper and Rabett 2014).

Dense forest cover during the terminal Pleistocene close to Kimanis is suggested by the diversity of arboreal taxa represented in the hunted assemblage such as the flying lemur (Cynocephalus variegatus), squirrels (Sciuridae) and sun bear.

The human communities appear to have engaged in broad spectrum foraging using a variety of capture techniques to trap various small carnivores, aquatic softshell turtles and monitor lizards, hunt cattle and deer and collect shellfish from local rivers.

The most abundant prey taxa are pigs, leaf monkeys and macaques - a hunting pattern similar to that observed at Niah during the terminal Pleistocene and Holocene (Piper and Rabett 2009). Rabett and Piper (2012) argued that the significant increase in hunting of arboreal primates at the end of the Pleistocene in Borneo and Java was possibly related to a combination of closure of the tropical rainforests resulting in larger monkey populations, and/or advances in technology as indicated by the appearance of bone projectile points as proxy evidence for the introduction of range weaponry. Although no osseous projectile points were identified at Kimanis, the presence of small stone tools suitable for hafting from Unit III onwards suggests that hafting technology was already present at the site from this period onwards.

The presence of Malay tapir in the Upper Birang region of East Kalimantan is an important new biogeographic record. In all likelihood this species is now extinct in Borneo but has been recorded in several archaeological assemblages in Sarawak from the Late Pleistocene to sub-recent times (Medway 1960; Cranbrook and Piper 2013; Piper and Cranbrook 2007). At Kimanis the oldest tapir bones were recovered from a layer between two radiocarbon dates of 13,543-10,774 cal. BP (ANU-11151) and 12,582-11,116 cal. BP (ANU-11150). The most recent record is from within the pottery-bearing deposits at Lubang Payau, which suggests the Malay tapir was still present in the late Holocene. The records from Sarawak and now East Kalimantan would suggest that the Malay tapir was formerly widespread across Borneo from the east to west coasts of the island. The presence of rhinoceros in the terminal Pleistocene also extends the known range of this large browser to the east coast of Borneo during the early and/or mid-Holocene. The Upper Birang remains may represent the Sumatran rhinoceros (Dicerorhinus sumatrensis) that is clinging to survival in Tabin National Park in Sabah (van Strien et al. 2008) and/or the Javan rhinoceros (Rhinoceros sondaicus) that is now extinct on Borneo, but has been identified in the archaeological record of Niah Cave (see Cranbrook 1986; Cranbrook and Piper 2007).

Another key feature of the late Pleistocene onwards in SEA is the emergence and spread of bone technologies. Van Es (1930) was the first to document the presence of osseous artefacts in layers predating ceramic horizons at the site of Gua Lawa, close to the village of Sampung in East Java. Subsequently, further investigations in the region resulted in the discovery of similar bone technologies within comparable stratigraphic locations just below the ceramic horizon at 19 other cave and rock shelter sites, and they probably all date to the early and/or mid-Holocene. Currently, the earliest records of bone technology come from the West Mouth of Niah Cave (Reynolds et al. 2013), Lang Longrien in the Thai Peninsula (Anderson 1990), Song Terus in East Java (Kusno 2006) and Matja Kuru II East Timor (O'Connor et al. 2014) variously dated to between 45,000 and 30,000 BP. By the early to mid-Holocene, osseous artefacts are relatively common across all of Mainland and ISEA (Rabett and Piper 2012). The earliest osseous artefacts recovered from Kimanis appear to coincide neatly with the observed rise in bone technologies at other sites across ISEA in the terminal Pleistocene/early Holocene. As at Kimanis and Lubang Payau bone tools appear to have served a variety of locally required functions, including piercing implements. 
The repertoire of stone debitage and other artefacts suggests the inhabitants of the Upper Birang region produced tools locally to undertake a variety of different tasks that included plant processing, butchery and hide working. The majority of lithic implements appear to have been produced expediently, utilised and discarded. However, use wear analysis also demonstrated that some artefacts were manufactured in order to shape wooden shafts for durable implements that would have been hafted.

There is evidence for the increasing use of pounders, grindstones and pestles and mortars for plant processing and grinding resins and minerals such as haematite across SEA in the early Holocene (Bellwood 1997: 181; Rabett et al. 2013; Simanjuntak 2002). The crystalline limestone pebble with evidence of ochre processing from Unit II falls within this category of artefact and probably dates to the mid-Holocene. The hammerstone reused as a grindstone from Unit III might imply that grinding technology extends back to the terminal Pleistocene in the Upper Birang region.

At least two burials were recorded in KMS/C4 Unit III and at the base of Unit II in KMS/TP. Though these burials could have been dug into preceding archaeological deposits from later phases of activity, the presence of tightly flexed inhumations in the terminal Pleistocene and early Holocene is consistent with other records across SEA. The emergence of these burial traditions seems to be linked to the regional development of complex new ideologies that, amongst other things, involved belief in the afterlife. At Niah, the two oldest interments recorded within the terminal Pleistocene/early Holocene burial grounds are both flexed, and date to 11,270-11,698 cal. BP (OxA-15157) and 8354-8454 cal. BP (OxA-16161) and are probably of a similar age to those discovered at Kimanis. The methods by which burials were treated at Niah were diverse and included flexion, seated inhumations, flexed decapitations and secondary burial. Cremation is another ritual behavior recorded at Niah (Lloyd-Smith 2012; Rabett et al. 2013). Several cremation burials have also been recovered at Ille Cave, Palawan Island in the Philippines. Samples of bone from Burial 758 produced dates of 9260-9006 cal. BP (OxA-16020) and 94259280 cal. BP (OxA-15982; Lewis et al. 2008). Close examination of bone surfaces indicated that this individual had been de-fleshed, dismembered and the long bones shattered prior to being burnt. Further examples of early to mid-Holocene (mostly flexed) burials include those from Gua Braholo, Song Keplek, Song Terus and Pawon on Java (Simanjuntak 2002; Détroit, 2006: 199; Noerwidi 2011/2012) and at Gua Cha, Gua Teluk Kelawar and Gua Peraling in Peninsular Malaysia (Zuraina Majid 2005).

During the mid-Holocene (KMS/C4, KMS/C8 and LPY/C3), foragers frequenting the Upper Birang continued to hunt and capture a diverse range of forest mammals and reptiles and collect Brotia sp. and freshwater crabs in rivers close to the caves and rockshelters. Contact with the coast is evident through the presence of several mangrove and marine species of mollusc that were utilised as decorative ornaments (Cypraea spp.) or as cutting or scraping tools (Geloina erosa). Similar tools have been found in caves and rockshelters in East Java such as Bale, Pawon, Peturon, Gede and Suruh in the northern Limestone Massif of Tuban (Willems 1939; van Heekeren 1972). Scrapers manufactured from Geloina erosa have also been reported from coastal and inland sites in East Timor like Lie Seri (Glover 1986: 75).

Use of forest plant products is evident through the presence of damar resin in Units I and II of LPY/C3, which indicates that this secreted resin was being used as an illuminant or a sealant. A small fragment of candlenut (Aleurites moluccana) from KMS/C8 might reflect use of this nut for its rich oil (Arifin 2004: 150-151).

Pottery first occurs in the archaeological record after $5000 \mathrm{cal}$. BP, and possibly as late as 2,000 years ago. All the pottery appears to have had a utilitarian function and consisted primarily of globular cooking pots. Fragments of rice chaff were identified in some of the pottery fabrics, suggesting that the visitors to the Upper Birang were either associated with or in contact with communities that 
produced or had access to rice agricultural products. However, none of the other material culture such as quadrangular stone adzes or stone and shell ornamentation associated with the regional appearance of Malayo-Polynesian speaking populations that have been identified at sites like Bukit Tengkorak in Sabah or the northern Philippines were recovered from the three Upper Birang archaeological sites. Thus, it is perhaps more likely that the communities inhabiting the rugged limestone regions of Berau maintained a forager lifestyle but had access to traded pottery from inhabitants of sedentary settlements nearby (Arifin 2006). Bulbeck (in Arifin 2004: 391) reached much the same conclusion through analysis of the teeth of the individuals recovered from preceramic $(\mathrm{N}=7)$ and ceramic $(\mathrm{N}=3)$ layers in the Upper Birang cave sites. He argued that the limited calculus build-up and absence of caries in both the terminal Pleistocene/early to mid-Holocene individuals, and those from the pottery-bearing horizons suggested that they all had a similar forager diet. The expansion of agriculture in the region might be quite a recent phenomenon.

\section{Conclusion}

The excavations of Liang Gobel, Lubang Payau and Kimanis have demonstrated that the limestone karst formations of the Berau region of Eastern Kalimantan possess cave and rockshelter sites with significant Late Pleistocene and Holocene archaeological records comparable with those recorded in Sabah and Sarawak. The investigations have shown that human frequentation of the Upper Birang River is evident from the terminal Pleistocene onwards, and potentially extends back at least as far as the end of the Last Glacial Maximum. Evidence for increased cave utilisation by larger human populations over prolonged periods along with a broadening of subsistence strategies and the proliferation in the hunting and trapping of arboreal taxa such as primates is a feature of human adaptation across Java and Borneo at the end of the Pleistocene. The increasing use of bone as a raw material from the Late Pleistocene onwards reflects similar trends observed across Mainland and ISEA, and the discovery of flexed inhumations and burnt human remains indicates that the local forager populations of Eastern Kalimantan were integrated into the social, cultural and ideological networks that were emerging across the region in the early Holocene.

\section{Acknowledgements}

This contribution is an excerpt from my $\mathrm{PhD}$ thesis research, which was funded by The Australian National University and UNESCO. I would like to thank my supervisor, Peter Bellwood, and various people for helping me with the analysis (Rokhus Due Awe, Colin Groves, Ken Aplin and Erik Meijaard (vertebrate faunal identifications), Ian Loch (mollusc identifications), John Seelley (geoarchaeological analysis), Peter Hiscock and Jo Kamminga (lithics analysis), Doreen Bowdery (phytolith identifications), Glenn Summerhayes (pottery analysis) and David Bulbeck (human remains identifications)) and drawings (Dubel Driwantoro and Mudjiono).

\section{References}

Anderson, D.D. 1990. Lang Longrien Rockshelter: A Pleistocene-Early Holocene Archaeological Site from Krabi, Southwestern Thailand. University Museum Monograph 71. Philadelphia: University of Pennsylvania University Museum.

Arifin, K. 2004. Early Human Occupation of the East Kalimantan Rainforest. Unpublished PhD thesis, The Australian National University, Canberra. 
- 2006. The Austronesian in Borneo. In T. Simanjuntak, I. Pojoh and M. Hisyam (eds) Austronesian Diaspora and the Ethnogenesis of People in Indonesian Archipelago, pp. 146-162. Jakarta: Indonesian Institute of Science.

Arifin, K. and B. Sellato. 1999. Gerabah Kalimantan terakhir yang tradisional: deskripsi ringkas tentang teknologinya. In C. Eghenter and B. Sellato (eds), Kebudayaan dan Pelestarian Alam: Penelitian Interdisipliner di Pedalaman Kalimantan, pp. 523-532. Jakarta: WWF Indonesia.

Barker, G. (ed.). 2013. Rainforest foraging and farming in Island Southeast Asia: The archaeology of Niah Caves Project Monographs Vol.1, Cambridge: McDonald Institute Monographs.

Barker, G., H. Barton, M. Bird, P. Daly, I. Datan, A. Dykes, L. Farr, D.D. Gilbertson, B. Harrisson, C.O. Hunt, T. Higham, J. Krigbaum, H. Lewis, S. McLaren, V. Paz, P.A. Pike, P. Piper, P. Pyatt, R. Rabett, T.E.G. Reynolds, J. Rose, G. Rushworth, M. Stephens, C. Stringer and G. Thompson. 2007. The 'human revolution' in lowland tropical Southeast Asia: the antiquity and behaviour of anatomically modern humans at Niah Cave (Sarawak, Borneo). Journal of Human Evolution 52: 243-261. doi. org/10.1016/j.jhevol.2006.08.011.

Barton, H., G. Barker, D. Gilbertson, C. Hunt, L. Kealhofer, H. Lewis, V. Paz, P.J. Piper, R.J. Rabett, T. Reynolds and K. Szabó. 2013. Later Pleistocene foragers $c$. 35,000-11,500 years ago. In G. Barker (ed.), Rainforest Foraging and Farming in Island Southeast Asia: The Archaeology and Environmental History of the Niah Caves, Sarawak, pp. 173-216. Niah Cave Project Monographs vol. 1. Cambridge: McDonald Institute Monograph Series.

Bellwood, P. (ed.). 1988. Archaeological Research in South-Eastern Sabah. Kota Kinabalu: Sabah Museum Monograph 2.

- 1989. Archaeological excavations at Bukit Tengkorak and Segarong, South-Eastern Sabah. Bulletin of the Indo-Pacific Prehistory Association 9: 122-162.

- 1997. Prehistory of the Indo-Malaysian Archipelago. 2nd edition. Honolulu: University of Hawaii Press.

Bird, M., D. Taylor and C. Hunt. 2005. Palaeoenvironments of insular Southeast Asia during the last glacial period: A savanna corridor in Sundaland? Quaternary Science Reviews 24: 2228-2242. doi. org/10.1016/j.quascirev.2005.04.004.

Bronk Ramsey, C. 2009. Bayesian analysis of radiocarbon dates. Radiocarbon 51: 337-360. doi. org/10.1017/S0033822200033865.

Brothwell, D.R. 1960. Upper Pleistocene human skull from Niah Caves, Sarawak. Sarawak Museum Journal 9 (n.s. 15-16): 323-349.

Bulbeck, D. 2004. Human remains from Kimanis Rockshelter and Lubang Payau, Kalimantan, Indonesia. Appendix 8.1 in K. Arifin, Early Human Occupation of the East Kalimantan Rainforest, pp. 376-398. Unpublished PhD thesis, The Australian National University, Canberra.

Chazine, J-M. 1994. New archaeological perspectives for Borneo and especially Kalimantan Provinces. Paper presented in the IPPA Conference, Chiang Mai, 1994.

- 2005. Rock art, burials, and habitations: Caves in East Kalimantan. Asian Perspectives 44(1): 219-230. doi.org/10.1353/asi.2005.0006.

Chazine, J.-M. and J.-G. Ferrié. 2008. Recent archaeological discoveries in East Kalimantan, Indonesia. Bulletin of the Indo-Pacific Association 28: 16-22. doi.org/10.7152/bippa.v28i0.12011.

Chia, S. 1997. The prehistory of Bukit Tenkgorak, Sabah, Malaysia. Journal of Southeast Asian Archaeology 21: 146-159. 
Cranbrook, Earl of. 1986. A review of fossil and prehistoric remains of rhinoceros of Borneo. Sabah Museum and Archives Journal 1 (n.s. 1): 50-110.

2000. Northern Borneo environments of the past 40,000 years: archaeozoological evidence. Sarawak Museum Journal 55 (n.s. 76): 61-109.

Cranbrook, Earl of and P.J. Piper. 2007. The Javan Rhinoceros Rhinoceros sondaicus in Borneo. The Raffles Bulletin of Zoology 55(1): 229-232.

- 2013. Paleontology to policy: The Quaternary history of South-east Asian tapirs (Tapiridae) and a proposal for the re-introduction of Malayan tapir Tapirus indicus to Borneo. Integrative Zoology 8: 95-120.

Datan, I. 1993. Archaeological excavations at Gua Sireh (Serian) and Lubang Angin (Gunung Mulu National Park), Sarawak, Malaysia. Kuching: Sarawak Museum Journal. Special Monograph no. 6.

Détroit, F. 2006. Homo sapiens in Southeast Asian archipelagoes: The Holocene fossil evidence with special reference to funerary practices in East Java. In T. Simanjuntak, I. Pojoh \& M. Hisyam (eds), Austronesian Diaspora and the Ethnogenesis of People in Indonesian Archipelago, pp. 186-204. Jakarta: Indonesian Institute of Science.

Freeman, J.D. 1957. Iban pottery. Sarawak Museum Journal 8 (n.s. 10): 153-176.

Glover, I.C. 1986. Archaeology in Eastern Timor, 1966-67. Terra Australis 11. Canberra: Department of Prehistory, Research School of Pacific Studies.

Harrisson, T. 1957. The Great Cave of Niah: a preliminary report on Bornean prehistory. Man 57: 161-166. doi.org/10.2307/2795279.

— 1958. The Cave of Niah: A history of prehistory. Sarawak Museum Journal 8 (n.s. 12): 549-595.

- 1970. The prehistory of Borneo. Asian Perspectives 13: 17-45.

Hooijer, D.A. 1960. The giant extinct Pangolin (Manis palaeojavanica Dubois) from Niah. Sarawak Museum Journal 9 (n.s. 15-16): 350-355.

Hunt, C.O., D.D. Gilbertson and G. Rushworth. 2007. Modern humans in Sarawak, Malaysian Borneo, during oxygen isotope stage 3: palaeoenvironmental evidence from the Great Cave of Niah. Journal of Archaeological Science 34(11): 1953-1969. doi.org/10.1016/j.jas.2007.02.023.

Kamminga, J. 1982. Over the Edge: Functional Analysis of Australian Stone Tools. Occasional Papers on Anthropology no. 12. St Lucia, Brisbane: University of Queensland Anthropology Museum.

Kusno, S. F. 2006. L'industrie osseouse de l'horizon Keplek, Holocène de la grotte de Song Terus, Punung, Java Est (Indonésie). Mémoire de Master. Paris: Muséum national d'Histoire naturelle.

Lewis, H., V. Paz, M. Lara, H. Barton, P. Piper, J. Ochoa, T. Vitales, A.J. Carlos, T. Higham, L. Neri, V. Hernandez, J. Stevenson, E.C. Robles, A. Ragragio, R. Padilla, W. Solheim II and W. Ronquillo 2008. Terminal Pleistocene to mid-Holocene occupation and an early cremation burial at Ille Cave, Palawan, Philippines, Antiquity 82: 318-335. doi.org/10.1017/S0003598X00096836.

Lloyd-Smith, L. 2012. Early Holocene burial practice at Niah Cave, Sarawak. Journal of Indo-Pacific Archaeology 32: 54-69.

Meijaard, E., Nijman, V. and Supriatna, J. 2008. Nasalis larvatus. The IUCN Red List of Threatened Species. Version 2015.2. www.iucnredlist.org. Downloaded on 30 June 2015. 
Medway, Lord. 1960. The Malay tapir in late Quaternary Borneo. Sarawak Museum Journal 9 (n.s. 15-16): 356-360.

Morrison, A. 1954-1955. Murut pottery. Sarawak Museum Journal 6 (n.s. 5): 295-296.

Morwood, M.J., T. Sutikna, E.W. Saptomo, K.E. Westaway, Jatmiko, R. Awe Due, M.W. Moore, Dwi Yani Yuniawati, P. Hadi, J.-X. Zhao, C.S.M. Turney, K. Fifield, H. Allen and R.P. Soejono. 2008. Climate, people and faunal succession on Java, Indonesia: evidence from Song Gupuh. Journal of Archaeological Science 35(7): 1776-1789. doi.org/10.1016/j.jas.2007.11.025.

Noerwidi, S. 2011/2012. The Significance of the Human Skeleton Song Keplek 5 in the History of Human Colonization of Java: A Comprehensive Morphological and Morphometric Study. Unpublished Master's thesis, Muséum National d'Histoire Naturelle, Paris.

O’Connor, S., G. Robertson and K.P. Aplin. 2014. Are osseous artefacts a window to perishable material culture? Implications of an unusually complex bone tool from the Late Pleistocene of East Timor. Journal of Human Evolution 67: 108-119. doi.org/10.1016/j.jhevol.2013.12.002.

Piper, P.J. and Earl of Cranbrook. 2007. The potential for large protected areas for the secure reintroduction of Borneo's lost 'Megafauna': A case for the Malay tapir Tapirus indicus. In R.B. Stuebing, J. Unggang, J. Ferner, J. Ferner, B. Giman and Kee Kum Ping (eds), Proceedings of the Regional Conference: Biodiversity Conservation in Tropical Planted Forests in South East Asia, pp. 161-168. Kuching: Forest Department, Sarawak Forest Corporation \& Grand Perfect Sdn Bhd. doi.org/10.1002/ oa.1046.

Piper, P.J. and R.J. Rabett. 2009. Hunting in a tropical rainforest: evidence from the terminal Pleistocene at Lobang Hangus, Niah Caves, Sarawak. International Journal of Osteoarchaeology 19(4): 551-565.

- 2014. Late Pleistocene subsistence strategies in Southeast Asia and their implications for understanding the development of modern human behaviour. In R. Dennell and M. Porr (eds), Southern Asia, Australasia and the Search for Modern Human Origins, pp. 118-134. Cambridge: Cambridge University Press.

- 2016. Vertebrate fauna from the Niah Caves. In G. Barker and L. Farr (eds), The Archaeology of the Niah Caves, Sarawak, vol. 2, pp. 401-438. Cambridge: McDonald Institute for Archaeological Research.

Piper, P.J., R.J. Rabett and Earl of Cranbrook. 2007. New discoveries of an extinct giant pangolin (Manis cf. palaeojavanica Dubois) at Niah Cave, Sarawak, Borneo: Biogeography, palaeoecology and taxonomic relationships. Sarawak Museum Journal 63 (n.s. 84): 207-226.

Rabett, R.J. 2002. Bone Technology and Subsistence Variability in Prehistoric Southeast Asia. Unpublished PhD thesis, University of Cambridge, Cambridge. doi.org/10.1017/ S0959774312000030.

Rabett, R.J. and P.J. Piper. 2012. The emergence of bone technologies at the end of the Pleistocene in Southeast Asia: Regional and evolutionary implications. Cambridge Archaeological Journal 22(1): 37-56.

Rabett, R.J., G. Barker, H. Barton, C. Hunt, L. Lloyd-Smith, V. Paz, P.J. Piper, R. Premathilake, G. Rushworth, M. Stephens and K. Szabó. 2013. Landscape transformations and human responses, c. 11,500-c. 4500 years ago. In G. Barker (ed.), Rainforest Foraging and Farming in Island Southeast Asia: The Archaeology and Environmental History of the Niah Caves, Sarawak, pp. 217-254. Niah Cave Project Monographs vol. 1. Cambridge: McDonald Institute Monograph Series. 
Reimer, P.J., E. Bard, A. Bayliss, J.W. Beck, P.G. Blackwell, C. Bronk Ramsey, C.E. Buck, H. Cheng, R.L. Edwards, M. Friedrich, P.M. Grootes, T.P. Guilderson, H. Haflidason, I. Hajdas, C. Hatté, T.J. Heaton, D.L. Hoffmann, A.G. Hogg, A.G., Hughen, K.F. Kaiser, B. Kromer, S.W. Manning, M. Niu, R.W. Reimer, D.A. Richards, E.M. Scott, J.R. Southon, R.A. Staff, C.S.M. Turney, and J. van der Plicht. 2013. IntCal13 and Marine13 radiocarbon age calibration curves 0-50,000 years cal BP. Radiocarbon 55 (4): 1869-1887. doi.org/10.2458/azu_js_rc.55.16947.

Reynolds, T., G. Barker, H. Barton, G. Cranbrook, L. Farr, C. Hunt, L. Kealhofer, V. Paz, A. Pike, P.J. Piper, R.J. Rabett, G. Rushworth, C. Stimpson and K. Szabó. 2013. The first modern humans at Niah c. 50,000-35,000 years ago. In G. Barker (ed.), Rainforest Foraging and Farming in Island Southeast Asia: The Archaeology and Environmental History of the Niah Caves, Sarawak, pp. 135-172. Niah Cave Project Monographs vol. 1. Cambridge: McDonald Institute Monograph Series.

Sémah, A.-M. and F. Sémah. 2012. The rain forest in Java through the Quaternary and its relationships with humans (adaptation, exploitation and impact on the forest). Quaternary International 249: 120-128. doi.org/10.1016/j.quaint.2011.06.013.

Simanjuntak, T. (ed.). 2002. Gunung Sewu in Prehistoric Times. Yogyakarta: Gadjah Mada University Press.

Spriggs, M. 1989. The dating of the Island Southeast Asian Neolithic: an attempt at chronometric hygiene and linguistic correlation. Antiquity 63: 587-613. doi.org/10.1017/S0003598X00076560.

Stimpson, C. 2016. Bird and bat bones from the Great Cave: taphonomic assessment. In G. Barker and L. Farr (eds), The Archaeology of the Niah Caves, Sarawak, vol. 2, pp. 439-454. Cambridge: McDonald Institute for Archaeological Research.

van Es, L.J.C. 1930. The prehistoric remains in the Sampoeng Cave, Residency of Ponorogo, Java, Proceedings of the Fourth Pacific Science Congress, Java, 1929. vol. III, Biological Papers, pp. 329-340. Batavia and Bandoeng: Pacific Science Association.

van Heekeren, H.R. 1972. The Stone Age of Indonesia. 2nd edition. The Hague: Martinus Nijhoff.

van Strien, N.J., Manullang, B., Sectionov, Isnan, W., Khan, M.K.M, Sumardja, E., Ellis, S., Han, K.H., Boeadi, Payne, J. and Bradley Martin, E. 2008. Dicerorhinus sumatrensis. The IUCN Red List of Threatened Species. Version 2015.2. www.iucnredlist.org. Downloaded on 3 July 2015.

Widianto, H, T. Simanjuntak and B. Toha. 1997. Ekskavasi situs Gua Babi, Kabupaten Tabalong, Propinsi Kalimantan Selatan. Berita Penelitian Arkeologi Balai Arkeologi Banjarmasin no. 1.

Willems, W. 1939. Merkwaardige praehistorische schelpartefacten van Celebes en Java. Cultureel Indië 1: 181-185.

Würster, C.M., M.I. Bird, I.D. Bull, F. Creed, C. Bryant, J.A.J. Dungait and V. Paz. 2010. Forest contraction in north equatorial Southeast Asia during the last glacial period. Proceedings of the National Academy of Sciences 107(35): 15508-15511. doi.org/10.1073/pnas.1005507107.

Zuraina Majid-Lowee, Z. 1981. The West Mouth, Niah in the Prehistory of Southeast Asia. PhD thesis, Yale University, 1979. Michigan: University Microfilm International.

Zuraina Majid (ed.). 2005. Perak Man and Other Prehistoric Skeletons of Malaysia. Penang: Universiti Sains Malaysia. 
This text is taken from New Perspectives in Southeast Asian and Pacific Prehistory, edited by Philip J. Piper, Hirofumi Matsumura and David Bulbeck, published 2017 by ANU Press, The Australian National University, Canberra, Australia. 